\title{
REVIEW
}

\section{Turbidity, arthropods and the evolution of perception: toward a new paradigm of marine phanerozoic diversity}

\author{
Brian M. Marcotte* \\ The Collegium, 35 Winfield Road, Providence, Rhode Island 02906-5008, USA
}

\begin{abstract}
Geological, paleo-oceanographic and paleoclimatological studies have independently demonstrated that the volume of preserved marine sediments, eustatic sea level, the depth to which the sea was oxygenated, the concentration of atmospheric oxygen and carbon dioxide and the amount of terrestrial rainfall fluctuated in a 400 million yr cycle over Phanerozoic time. These data are used to develop the hypothesis that the level of oceanic turbidity co-varied with these changes and that turbidity was the motor, plate tectonics the tempo and perception the mode of evolution in Phanerozoic seas. This hypothesis predicts that during turbidity maxima (Silurian-Devonian, Jurassic-Tertiary), animals with non-visual foraging and predator-avoidance mechanisms and adaptations to marine pelagic, freshwater and terrestrial habits should diversify. During turbidity minima (late-PrecambrianCambrian, late-Carboniferous-Triassic), animals with visual sensory modalities and benthic habitat specializations should diversify. At the boundary of these environmental conditions, alternating mass extinctions of these adaptive characters and the taxa possessing them should occur. Patterns in the evolution of perceptual modalities, foraging strategies, predator avoidance mechanisms, habitat specializations and inferred aspects of behavioral ecology of aquatic arthropods, i.e. adaptive characters that are less sensitive to instantaneous changes in diversity than are the taxa that carried them, are used to test these predictions. Trilobite diversification and extinction; the adaptive radiation of ostracods and eumalacostracan crustaceans; the iterative evolution of small, fast-moving entomostracan crustaceans; and the evolution of terrestrial chelicerates and decapod crustaceans are all consistent with these predictions. In short, the history of aquatic evolution in Phanerozoic seas can be told in the evolution of perception. Data as disparate as the diversification and extinction of marine plants, cephalopod mollusks and fish are also consistent with predictions deduced from this hypothesis.
\end{abstract}

KEY WORDS: Methodological solipsism - Uniformitarianism - Mass extinction - Neoteny · Body sizeenvironmental frequency relationships - Vision - Crustacea - Trilobita

\section{INTRODUCTION}

The taxonomic diversity of marine organisms fluctuated during Phanerozoic time (see Fig. 1 for pattern of marine diversity and definitions of geologic time intervals) and these fluctuations were partitioned among several temporal frequencies (e.g. Raup \& Sepkoski 1984, 1988, Fischer 1988, Raup 1993). Low frequency secular trends in earth evolution with periods $>400$ million years (Myr) have been recognized and correlated

-E-mail: brianmarcotte@thecollegium.org with variations in eustatic sea level, cyclic variations in biogeochemistry and climate and with rates of sedimentation (e.g. Nance et al. 1986, 1988, Worsley et al. 1986). Higher frequencies, with periods of $26,32,85$ and $250 \mathrm{Myr}$, have been correlated with cosmic events: falling asteroids, comets and meteorites and the sun's oscillation about the galactic plane (e.g. Hatfield \& Camp 1970, Salop 1977, Alvarez et al. 1984, Rampino \& Strothers 1984). Still higher frequency events have also been recognized. For example, climate cycles of 0.4 to 6.0 Myr duration have been observed in lake sediments from the Permian (Kerr 1991), abrupt changes in world 


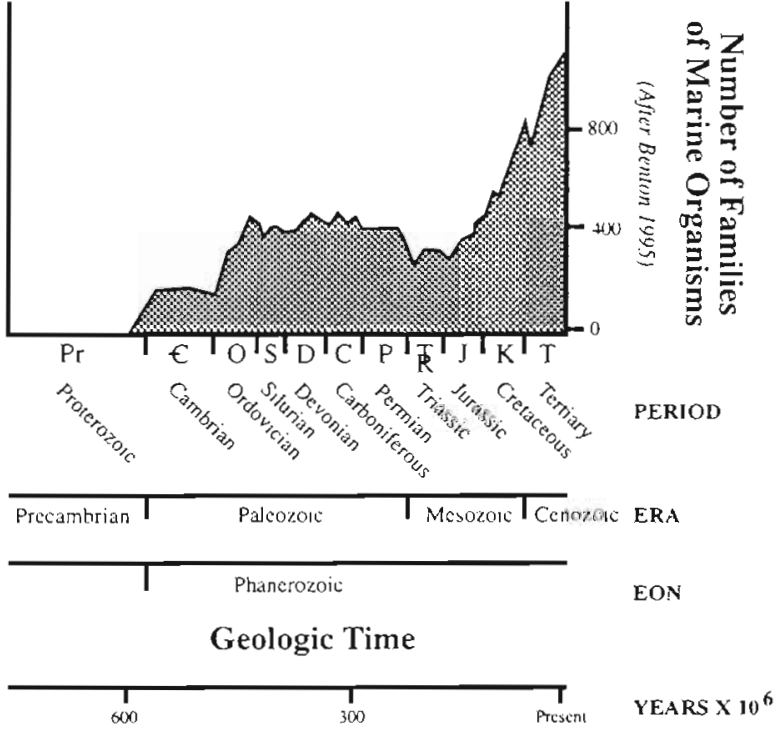

Time Before Present

Fig. 1. Marine taxonomic diversity through geologic time with names, abbreviations and temporal relationships of geologic time intervals. The Proterozoic period began at the end of the Archean (Katarchean) period, 3500 Myr before present, and ended at the start of the Cambrian, 570 Myr before present

climates spaced at $100000 \mathrm{yr}$ intervals have been recognized during glaciation events (Broecker \& Denton 1989, Liu 1992) and the biodiversity of deep-sea ostracods has been related to changes in solar insulation caused by 41000 yr cycles in the tilt of the earth (Cronin \& Raymo 1997)

Fig. 2. Abundance of turbidity-sensitive marine taxa through the Phanerozoic eon. Variables and axes are designated on each graph. Density of stippling indicates relative levels of turbidity in each Period. Abbreviations for geologic periods are defined in Fig. 1. (A) Immobile suspension feeders inhabiting rock substrates in contemporary seas are known to be at greatest risk of extinction with rising turbidity; their fossil antecedents flourished only in the clear waters of the late Carbonifterous-Triassic. (B) Suspension feeders adapted to sedimentary habitats in contemporary seas thrive in turbid environments; their antecedents flourished during times of high turbidity (Silurian-Devonian) and declined precipitously in the clearing waters of the late Carboniferous-Triassic (C) Suspension-feeding bivalve molluscs which live attached to surfaces and are free lying on the bottom of contemporary seas are adversely affected by turbidity. The abundance of their fossil ancestors fell during times of high turbidity and rose during times of clear water. (D) Colonial corals, which, based on the distribution of contemporary colonial corals, required clear waters to flourish, declined during the times of high turbidity and increased in diversity during the clear waters of the late Carboniferous-Triassic; solitary corals are less sensitive to turbidity and flourished during times of hight. turbidity
Sample size and the longevity of fossil organisms bias quantitative estimates of taxonomic diversity. For example, variations in the volumes of preserved sediments from each geological period result in variations in the sample sizes available for fossil organisms living at a particular time (Raup 1972, Signor 1982), Variations in the survivorship of specific taxa may bias samples of

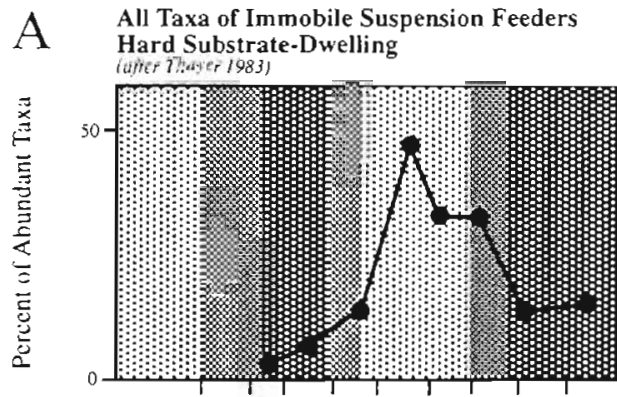

B All taxa of Immobile Suspension Feeders Sediment-Dwelling
(affer Tha ter ls:3)

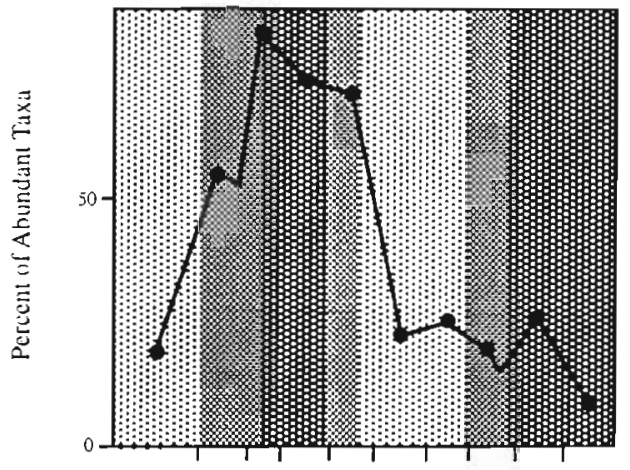

C $\quad \begin{aligned} & \text { Endobyssate and Free Lying } \\ & \text { Suspension Feeding Bivalve Molluscs } \\ & \text { (uffer Thajer 1983) }\end{aligned}$

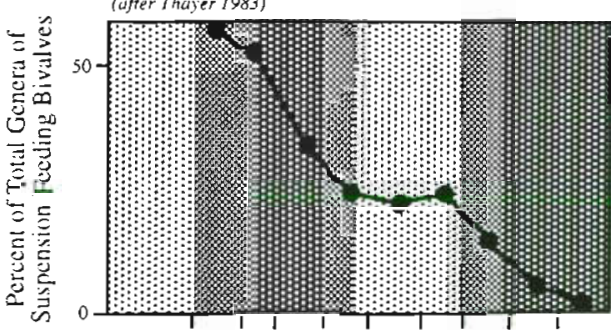

D Colonial and Solitary Zoantharian Corals

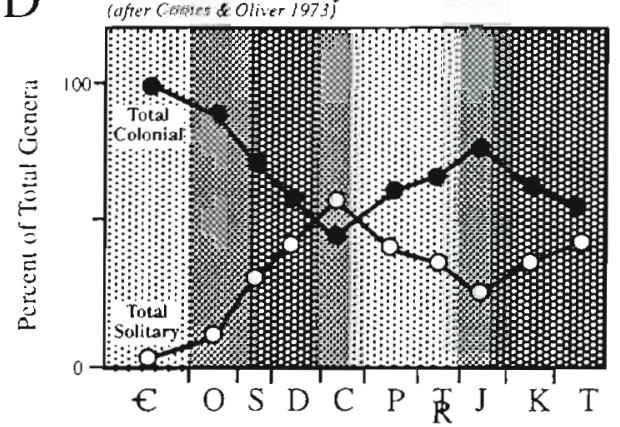

Geologic Periods 
the fossil record in a related way (Norris 1991). Further, stratigraphy is not a continuous recorder of evolutionary change; the geological mechanisms (e.g. turbidity currents) which help create much of the fossil record are episodic. The fossil record produced is an aliased sample (Blackman \& Tukey 1958) and, accordingly, very high frequency events are not considered further.

Sampling bias and alias notwithstanding, one ecological explanation of low frequency fluctuations in marine diversity during the Phanerozoic eon has dominated paleontology (e.g. Valentine 1973, Sepkoski et al. 1983): diversity is positively correlated with tectonically induced changes in the areal extent and provinciality of the shallow water habitats in which the majority of fossil marine organisms lived (Signor 1982). Continental fusion led to competitive exclusions and mass extinctions; continental fission led to allopatric speciation and taxonomic diversification.

Although the explanation outlined above adequately predicts the general low frequency trends in marine diversity during Phanerozoic time, it cannot explain the cause of extinctions and diversifications in turbiditysensitive taxa out of phase with this trend, e.g. members of the Anthozoa, Cephalopoda, Bryozoa, Brachiopoda, Pelmatozoa, Trilobita and malacostracan Crustacea. These differences in the times of extinction of turbidity-sensitive taxa are vividly illustrated by historical changes in their relative abundances (Fig. 2) and the relative contribution of these taxa to carbonate sediments (Blatt et al. 1972).

It is the purpose of this review to offer a new hypothesis that can explain both the low frequency trend in marine Phanerozoic diversity and its outliers: diversifications and extinctions were mediated by alternating levels of oceanic turbidity. This hypothesis will be tested in detail using biological characteristics (sensory modalities, foraging strategies, predator avoidance mechanisms and habitat selection) of aquatic arthropods and, more generally, by examining trends in the evolution of such disparate taxa as algae, fish and mollusks. In proposing this hypothesis, it is recognized that many biological traits contribute to the vulnerability of marine taxa to extinction (cf. McKinney 1997); nevertheless, long-term trends in extinctions and diversifications can be discerned and correlated with a single variable: turbidity.

\section{TURBIDITY HYPOTHESIS}

During the early Proterozoic period (about $2600 \mathrm{Myr}$ ago) the earth's continents were grouped together about the South Pole (Fig. 3) (Piper 1982, 1987). The position of continental blocks or cratons relative to one another within this supercontinent is still controversial

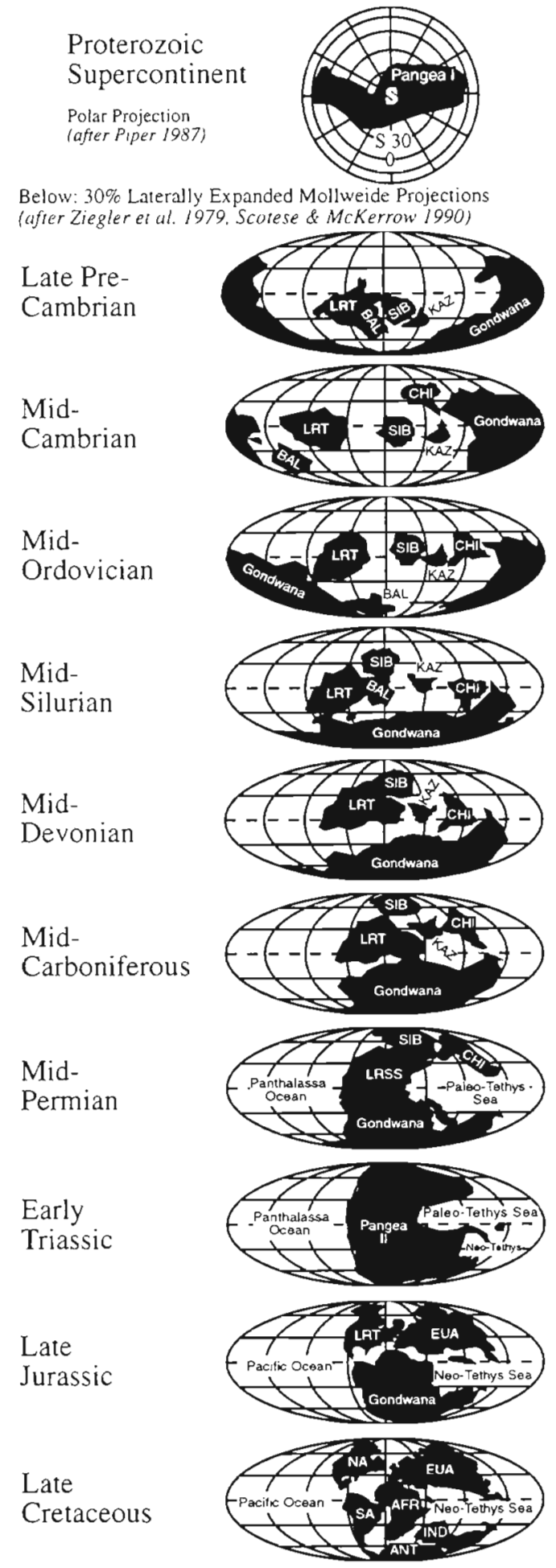

Fig. 3. Geographical movements of continental plates through geologic time. Pangea I designates Piper's (1987) Proterozoic supercontinent at 2600 Myr before present. Continental blocks or cratons are identified with the following abbreviations: $\mathrm{AFR}=$ Africa, $\mathrm{ANT}=$ Antarctica, $\mathrm{BAL}=$ Baltica, $\mathrm{CHI}=$ China, $\mathrm{EUA}=$ Eurasia, $\mathrm{IND}=$ India, $\mathrm{KAZ}=$ Kazakhstania, LRSS $=$ Laurussia, LRT $=$ Laurentia, NA $=$ North America, $\mathrm{SA}=$ South America, $\mathrm{SIB}=$ Siberia 

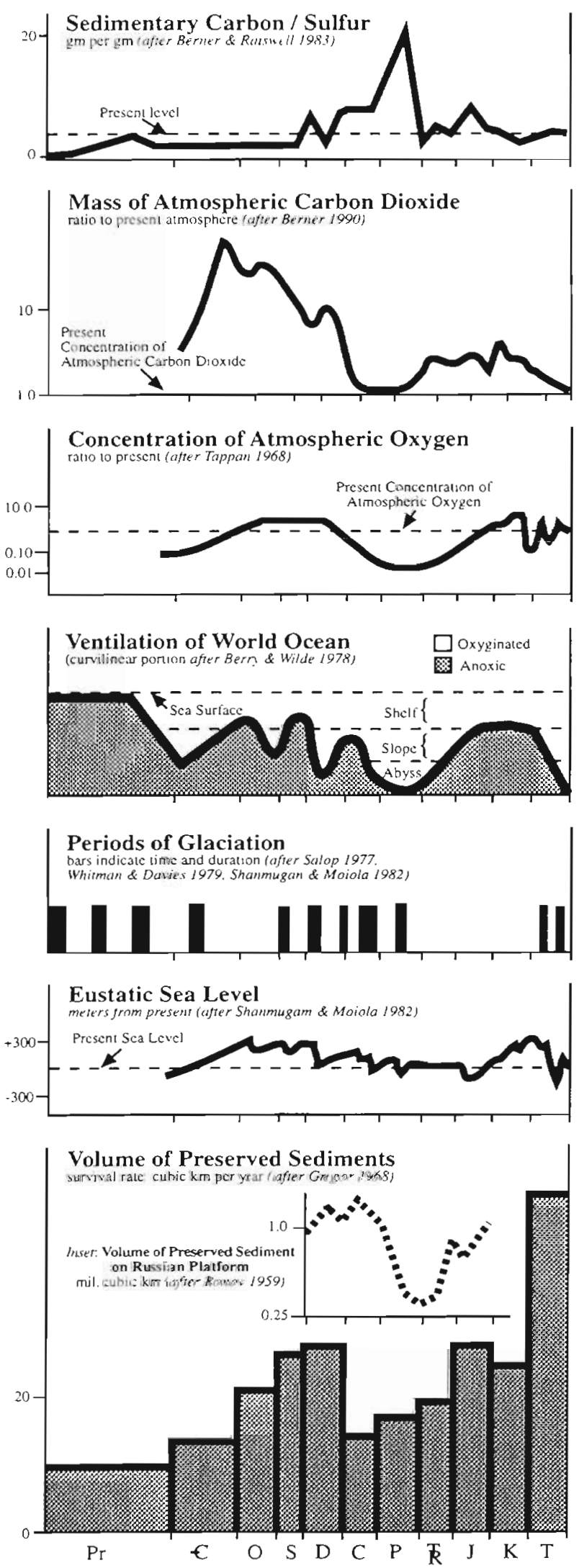

Geologic Periods especially for the period beginning 1100 Myr ago (e.g. Young 1995, Weil et al. 1998). Appellations for this supercontinent differ according to specific cratonic conformations. For simplicity, this first supercontinent is here termed Pangaea I.

During the late-Proterozoic (725 Myr ago), Pangaea I progressively broke into parts, some of which moved laterally and north at different rates (Bond et al. 1984, Hoffman 1991, Powell et al. 1993), while others became consolidated about the South Pole to form the paleocontinent of Gondwana (Fig. 3) (e.g. Ziegler et al. 1979). The continents converged to form Pangaea II during the Permian-Triassic only to break apart again during the late-Mesozoic and Cenozoic eras.

Although modified by post-depositional forces, the volume of marine sediments preserved per unit time in the geological record covaried with these tectonic movements (Fig. 4). These variations reflect real changes in depositional environments. The rivers of today discharge 13.3 billion tons of sediment each year into the world ocean (Milliman \& Meade 1983). At this rate, more than 3 times the weight of all recent and ancient sediments would have been deposited since the Cambrian. One can explain these variations with a simple model of tectonic movements of the earth's crust and resultant changes in paleoclimates and paleo-oceanography.

During periods of continental convergence and mountain-building, low volumes of sediment accumulated in the sea because of intermontane deposition (e.g. Garrels \& Mackenzie 1971). During periods of continental divergence, intermontane deposits were eroded and washed into the sea. Gregor (1968) has argued that land plants reduced sediment erosion during the Permian and, thus, decreased the volume of sediments preserved from this time. This hypothesis, however, did not consider the dry climatic conditions during the Permian-Triassic or its negative effects on terrestrial vegetation.

As the land masses of Pangaea I moved apart, they travelled through zones of high latitude winds. Moisture gathered by these winds from numerous large intercontinental waterways resulted in wet weather and increased terrestrial erosion (e.g. Broadhurst \& Loring 1970). With Pangaea II, the continental plates were joined at the equator but most of the continental surface area lay in the horse latitudes; the trade winds blew predominately over land. Further, mountain chains,

Fig. 4. Changes in physical, chemical and geological variables through geologic time. Variables and axes are designated on each graph. Abbreviations for geologic periods are defined in Fig. 1. Depth of ventilation of world ocean during the Proterozoic cannot be determined with certainty. Durations of periods of glaciations are indicated by bar width 
which rose along the contact boundaries of Gondwana and Laurussia as Pangea II was formed, blocked the moist equatorial easterlies (Ziegler et al. 1979). The result was generally warm, dry weather and decreased terrestrial erosion (Robinson 1973, see also Manabe \& Broccoli 1990). Thus, long-term fluctuations in marine sedimentation rates may have been compounded by the effects of continental movements on terrestrial climates (Robinson 1973, Frakes 1979). These factors and concurrent changes in sea level combined to affect oceanic turbidity during the Phanerozoic.

When continents converged, sea level fell (Worsley et al. 1984) (Fig. 4). The small volumes of sediments eroded from continental platforms at these times were channeled into large geographically discrete drainage basins containing many tributaries but with only 1 major outlet to the sea, like the Mississippi, Amazon, and Yangtze Rivers of today (e.g. Tipper 1975, Worsley \& Broadhurst 1975, Milliman \& Meade 1983). Suspended solids carried by these river systems were deposited in a small number of large estuaries. The combination of low sediment volume and restricted depositional area would have lowered the average turbidity of coastal waters. When continents diverged, sea level rose and terrestrial drainage basins were flooded as midoceanic mountain systems were built (Valentine \& Moores 1970, 1972). This resulted in vast, shallow, inland seas, into which many small rivers (former tributaries) flowed (e.g. Bowen et al. 1974, McGhee \& Sutton 1981\}. Turbidity increased.

During periods of continental convergence, more than half the globe was a single ocean. Weather was monsoonal (Valentine \& Moores 1970, 1972). Ocean fetch, the distance of open water over which wavegenerating winds blew (Neuman \& Pierson 1966), was maximal, as were wave lengths. Swells broke in deep water offshore. Storm- and wave-driven perturbations in shallow, nearshore habitats would have been infrequent and of long duration. With continental fission, rift valleys became shallow waterways and inland seas in which small, frequent storms generated enough turbulence to scour the shallow bottom, keep sediments in suspension and disperse them oceanward (e.g. Bowen et al. 1974, McGhee \& Sutton 1981). The sea would have been more turbid in coastal habitats and near the bottom, i.e. in the 'nepheloid layer' (Berner 1976, Dryer 1976), and less turbid in the open ocean far from land and in surface waters (e.g. Balsam \& Deaton 1991). Changes in the spatial and temporal scale of ocean turbulence would have substantially influenced sedimentation rates and feeding tactics (Kiørboe 1997).

Nearshore marine habitats were a source of much faunal diversity throughout the Phanerozoic eon (Sepkoski 1991); marine animals were probably restricted to shallow water habitats during this time because deeper environments were only sporadically oxygenated. It was not until the end of the Carboniferous, when prolonged glaciation (Fig. 4) had resulted in sufficient downward-moving currents of cold oxygenrich water to ventilate the deep sea, that colonization of deep water environments occurred (e.g. Berry \& Wilde 1978, Jablonski et al. 1983, Wilde \& Berry 1984). Resuspension and lateral transport of sediments in marine water below $2800 \mathrm{~m}$ may also have occurred with glacially intensified deep water circulation (Francois \& Bacon 1991)

Though there is no known causal relationship, it is interesting to note that, during the ventilation of the deep sea, $\mathrm{O}_{2}$ levels in the atmosphere decreased (Fig. 4). Lack of glaciations during the Triassic-earlyTertiary may have resulted in repeated oxygen depletions or at least expansion of the oxygen minimum zone into deep ocean environments (Schlanger \& Jenkyns 1976, Waples 1983 , Isozaki 1997). Thus, it was to shallow marine habitats, with their fluctuating levels of turbidity, that organisms such as aquatic arthropods became adapted.

The concentration of atmospheric $\mathrm{CO}_{2}$ also varied over Phanerozoic time. Berner (1990) developed a mathematical model for the paleogeochemistry of $\mathrm{CO}_{2}$ that included the terrestrial, atmospheric and aquatic chemistry of $\mathrm{CO}_{2}$ and carbonates and many of the paleogeographic variables discussed above. His model predicted that atmospheric $\mathrm{CO}_{2}$ was greatest during the Cambrian and Ordovician, declined during the Devonian to a low in the Carboniferous, rose to intermediate levels during the Jurassic-Cretaceous and fell to present day levels (comparable to the low of the Carboniferous) during the Tertiary (Fig. 4). Because carbon dioxide absorbs solar radiation, it traps heat in the atmosphere and creates a 'greenhouse effect'. Accordingly, warm global temperatures would have occurred during times of high concentrations of $\mathrm{CO}_{2}$ (CambrianOrdovician, Jurassic-Cretaceous) and low temperatures during periods of low concentrations (Carboniferous, Tertiary). Berner's model is in strong agreement with Fischer's (1988) supercycle model of phanerozoic environments with its alternating 'greenhouse-icehouse' effects. Changes in solar activity and in the concentration of other greenhouse gases and atmospheric dust may modify these models further (e.g. Hansen \& Lacis 1990, Hansen et al. 1990, Kerr 1999).

From the above geological, paleo-oceanographic and paleoclimatological evidence, it is reasonable to hypothesize that oceanic turbidity fluctuated during the Phanerozoic eon in habitats important to the survival and diversification of marine invertebrates. It also seems reasonable to use the volume of preserved sediments in the geologic record as an index of long-term variations in oceanic turbidity. The data of Ronov 
(1959) (Fig. 4), which are more detailed than those of Gregor (1968), are used here to predict the turbidity nadir at the Permo-Triassic boundary. Short-term (high frequency) fluctuations in oceanic sedimentation rates are also known (from Cenozoic deep-sea deposits) and firmly establish that variations in sedimentation rates (and thus turbidity) in the world's oceans are synchronous global phenomena (Davies et al. 1977. Whitman \& Davies 1979). Exceptions to this turbidity hypothesis include local conditions that might have differed from the world-wide trends and may have served as refuges for some taxa (e.g. mid-ocean habitats/islands: cf. Lisitzin 1972, Leg 138 Shipboard Scientific Party 1991; and areas of high bioresuspension: cf. Graf \& Rosenberg 1997)

\section{BIOLOGICAL TESTS OF THE TURBIDITY HYPOTHESIS: THE AQUATIC ARTHROPODS}

Solids suspended in water reflect and scatter light (e.g. Duntley 1962). Turbidity reduces the depth to which light can penetrate water, increases the luminosity of water and decreases visual contrast (Jerlov 1976, Lythgoe 1979, Loew \& McFarland 1990). Organisms that relied on vision to locate food and predators would have been profoundly affected by fluctuations in ocean turbidity.

Aquatic arthropods could adapt to turbid waters in at least 4 ways: (1) by increased visual acuity and lightsensitivity, (2) by enhanced non-visual perceptual modalities, (3) by swimming above the nepheloid layer and (4) by concomitant changes in foraging strategies, competitive networks and predator avoidance mechanisms (e.g. Marcotte 1983, Eiane et al. 1997).

\section{Adapting to turbidity: the trilobites and their relatives}

Among the first aquatic arthropods were the trilobites and their trilobite-like relatives (Harrington 1959). Most Cambrian trilobites were bottom-dwelling detritivores and/or scavengers. A number of lines of evidence have indicated that most trilobites ate by entraining small food items in water currents generated in a median ventral food groove; the food was transported anteriorly to the mouth and ingested (e.g. Bergström 1973). In most taxa, cephalic appendages were not highly specialized for feeding (but see review in Hessler \& Newman 1975).

At the height of trilobite diversity (upper Cambrian), 63 families are recognized (Clarkson 1975). Of these, $86 \%$ had large compound (or 'holochroal') eyes with which they located food and predators (Fig. 5). These eyes were usually kidney-shaped in dorsal view and
A Images in Lenses (after Towe 1973)

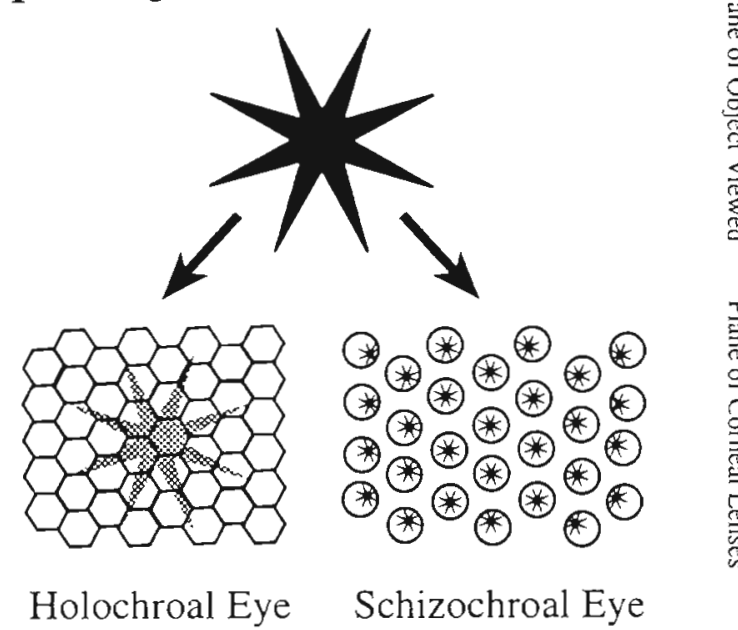

\section{B Relative Abundance (after Clarkson 1975)}

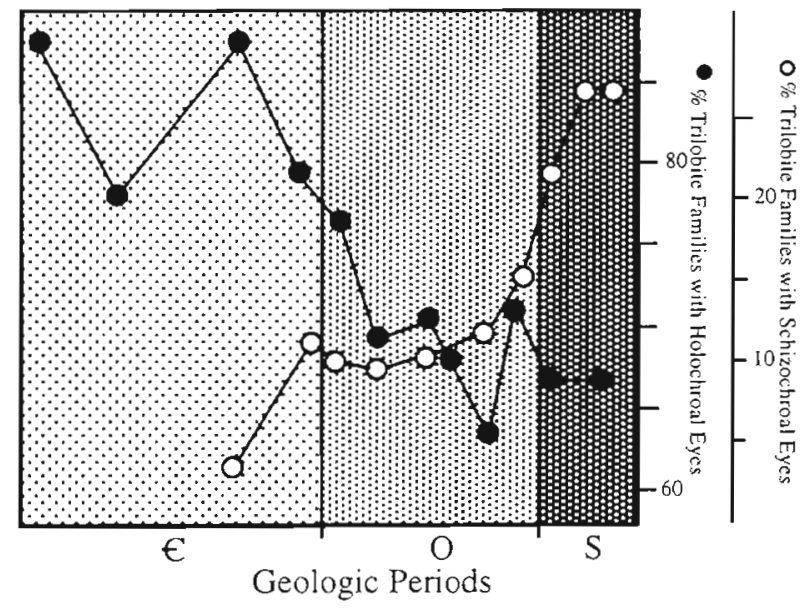

Fig. 5. (A) Images produced in the lens of the 2 major types of trilobite eyes. Holochroal lenses produce a mosaic image. Schizochroal lenses produce a composite image. (B) Relative abundance of trilobite taxa with holochroal and schizochroal eyes during geologic time. Abbreviations for geologic periods are defined in Fig. 1 Density of stippling indicates relative levels of turbidity in each period

slightly dorsally convex in cross section. They were covered by a single corneal layer below which lay a faceted lens. Light rays entering the eye converged resulting in a single mosaic image.

As turbidity rose during the Ordovician-Silurian, trilobite diversity fell from its high in the upperCambrian to 15 families at the end of the Silurian. Extinctions occurred more often among taxa inhabiting shelf environments (Fortey 1975, 1989) than among deep water taxa; shelf habitats are universally more turbid than deep waters. Several members of the Illaenids, a trilobite family with holochroal eyes, sur- 
vived into the Permian (Clarkson 1975); illaenids were abundant in reef environments (Bergström 1973, Mikulic 1981) that were de facto (see below) low turbidity habitats. Most trilobites with holochroal eyes became extinct by the middle-Ordovician (Fig. 5) (Moore 1955-1969, Stubblefield 1959, Clarkson 1975).

From the late-Cambrian to the Devonian, a new suborder of trilobites evolved: the Phacopina. Many of the families in this suborder amplified their feeding efficiency by secreting a sticky substance into the region just posterior to the mouth: food was formed into a bolus before ingestion (Eldredge 1971). In one group of Phacopina, the dalmanitids, large anterior cephalic appendages became the dominant means of manipulating food into the mouth (Eldredge 1971).

Most Phacopina trilobites viewed their environment through a new type of eye: the composite or 'schizochroal' eye (e.g. Clarkson 1975). Each lens of this eye had its own cornea and light receptor (Fig. 5). The field of view was broken into many partially overlapping images, each with its own unique perspective (Towe 1973, Clarkson \& Levi-Setti 1975, Fortey \& Morris 1977). Light incident on 1 'reference' element of this ocular array could have been used to 'zero' the backgrounds of other visual elements, resulting in contrast enhancement. This configuration of visual elements would have helped to increase the distance over which the Phacopina could perceive and react to predators and prey (see also Eiane et al. 1997). Further, lateral inhibition of adjacent elements in the visual array may have permitted analysis of covariance in the field of view at the level of the eye, thus facilitating rapid pattern recognition much as 'perceptrons' do in patternrecognizing computers (Rosenblatt 1962, Block et al. 1964, Ullmann 1973). The potential for enhanced contrast and rapid pattern recognition promoted predatory behaviors attributed to the Phacopina (e.g. Bergström 1969) and allowed for the rapid increase in their diversity during the late-Ordovician and Silurian (Fig. 5).

Efficient predators must not only recognize prey quickly but also must be able to estimate prey size and strike/pursuit distance (e.g. Schoener 1979, Maiorana 1981), skills made possible by stereoscopic vision in the Phacopina (e.g. Cowen \& Kelley 1976, Aksnes \& Utne 1997). As the Phacopina diversified during the Silurian-Devonian rise in turbidity, their eyes became reoriented to provide greater frontal vision (Fig. 6) (McNamara 1980). Non-visual sense organs (probable chemo- and proprioreceptors) increased in number and breadth of distribution on their bodies (Miller 1974/75, Chlupac 1975, McNamara 1980).

The adaptive advantage of schizochroal over holochroal eyes in environments of increasing turbidity can also be seen in the differential longevity of taxa bearing these traits (from range data in Clarkson 1975)
Taxa with schizochroal eyes survived twice as long on average as did taxa with holochroal eyes. Nevertheless, taxa with schizochroal eyes remained primarily visual foragers and were extinct by the end of the first Phanerozoic turbidity maximum during the SilurianDevonian (Clarke 1889, Clarkson 1967, 1975, Eldredge 1972). Before the Devonian extinction of the Phacopina, however, schizochroal eyes in some phylogenetic lineages were reduced in size and lens number. Feist (1995) has shown that, within these phylogenetic lineages, typical ancestral forms at the start of the Devonian had 86 lenses. Typical forms derived from these ancestors in the latter half of the Devonian had only 12 lenses and at the end of the Devonian had only 1 or a few lenses or the derived taxa were entirely blind.

Blind trilobites occurred in several other phylogenetic lineages within the Trilobita (Clarkson 1975). The earliest blind trilobites, the Agnostida, were small $(<1.0 \mathrm{~cm}$ long), had cosmopolitan distributions and were probably planktonic, but little is known of their biology (Fig. 6) (Robinson 1972, 1975, but see Müller \& Walossek 1987). All other blind trilobites and trilobitelike taxa were bottom-dwelling detritivores and carnivores, e.g. Emeraldella (Fig. 6), Cryptolithus, and Molaria (Campbell 1975, Whittington 1975, 1977, 1981, Bruton 1981). They probably selected food from among nutritionally inert materials by exploiting the special physical and chemical properties at the sedimentseawater interface (Dryer 1976). In this 'benthic boundary layer' (BBL), frictional forces result in an exponential decrease in water velocity as depth increases (Hinze 1959, Neuman \& Pierson 1966, Wimbush 1976). Water movements, universally governed by viscous and inertial forces, are here viscosity dominated. The result is non-turbulent (or laminar) movement of water (e.g. Hinze 1959, Wimbush 1976, Purcell 1977). Chemicals excreted or consumed by bottomdwelling food organisms produce positive or negative concentration gradients ('halos') that diffuse slowly in the BBL and move across the bottom along predictable trajectories (Berner 1976, Purcell 1977). Blind benthic foragers with chemoreceptors on long first antennae and elsewhere on their bodies probably used these chemical gradients to locate patches of food as crustaceans do today. For example, proprioreceptors, sensitive to the frequency and direction of slight pressure changes and water movement, permitted the detection of moving competitors, prey and predators, as well as shifting current directions (e.g. Strickler 1975a,b, McNamara 1980, Marcotte 1984, Wong 1996). The terrace lines of trilobites may have served this propriosensory function (Miller 1975, Schmalfus 1981). Other structures thought to be chemo- and proprioreceptors are numerous and widely distributed on the bodies of blind trilobites (Miller 1974/1975) 


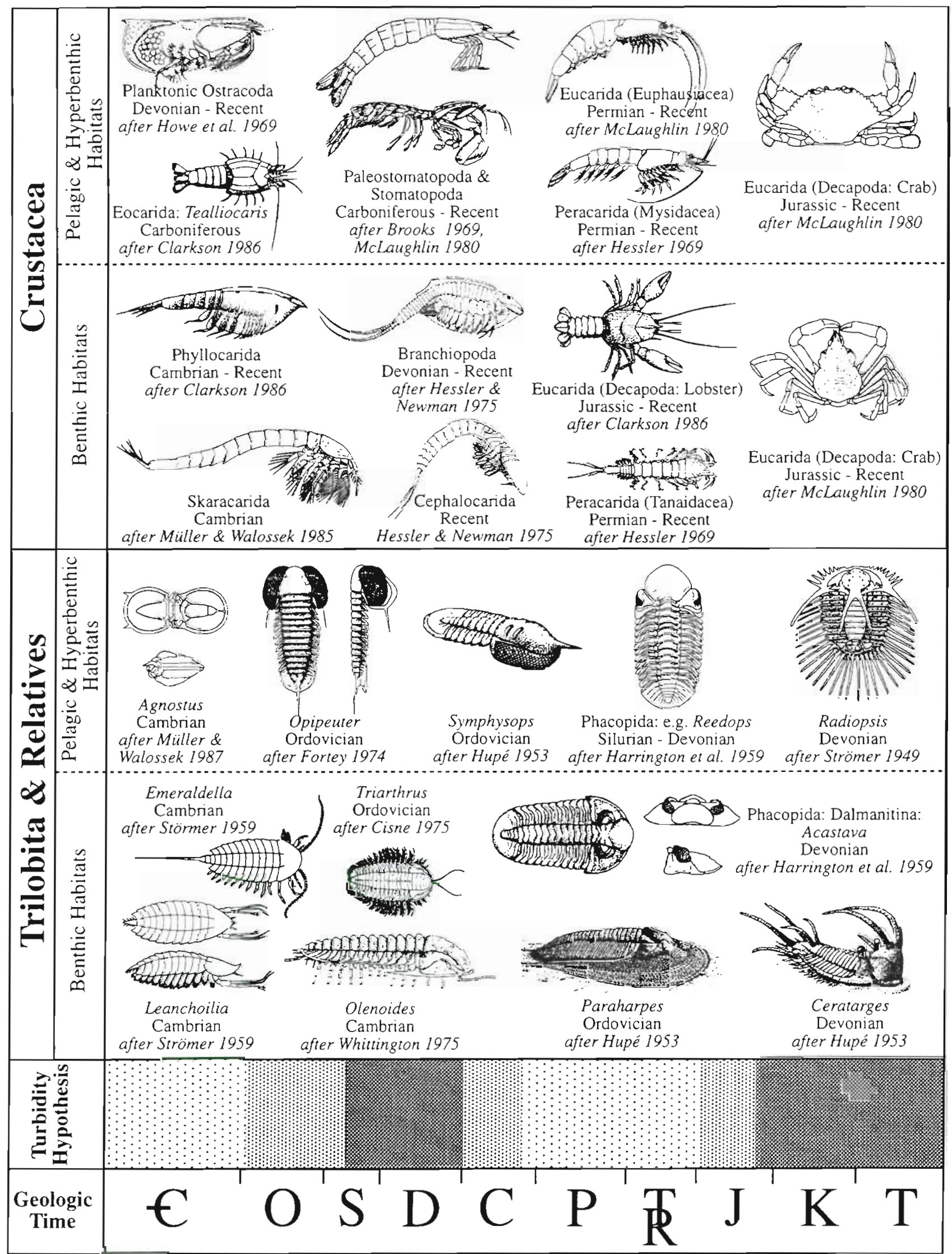


In addition to sensory adaptations, trilobites and trilobite-like taxa adapted to turbidity by (weakly) swimming above the nepheloid layer and inhabiting less turbid pelagic habitats. This evolutionary strategy, of which Symphysops, Opipeuter (Fig. 6) and Prospectatrix are early examples, arose independently in at least 5 trilobite phylogenies (Fortey 1981) during the increasing turbidity of the Ordovician. In the pelagic realm, trilobite visual sensory modalities became modified in derived forms. The Phacopina had schizochroal eyes; others retained the ancestral holochroal eye and survived the Ordovician-Silurian extinctions with gross anatomical adaptations of the eye (cf. Fortey 1974, 1985) (Fig. 6) including: (1) enlargement, e.g. Symphysops, Opipeuter, (2) conical projections or stalks that held the eyes above the surface of the head, e.g. Carolinites and Sidneyia and/or, (3) orientation so that part of their visual surface was directed downward, e.g. Cyclopygacea: Prospectatrix. It is clear from these data that visual adaptations were numerous among Silurian trilobites, as predicted by the turbidity hypothesis.

Trilobites and trilobite-like taxa were vulnerable to predation in the Silurian - 'The Age of Fish' (Romer 1968). As protection against these predators, benthic taxa evolving at this time, such as Ceratarges (Fig. 6), had long dorsal spines; contemporaneous pelagic taxa often had long sharp spines on their dorsal and lateral surfaces (e.g. Radiopsis, Fig. 6) both for protection from predators and for floatation.

Some aquatic arthropods mixed the strategy of swimming with relatively non-selective suspension-feeding (Bruton 1981, Whittington 1981). This conclusion is inferred from morphological similarities with extant Crustacea (e.g. Cannon 1933, Briggs 1977, 1978). Some of these include the Cambrian trilobites and the trilobitelike taxa (e.g. Leanchoilia, Opabinia and perhaps Sarotrocerus), the pseudo-notostracans, the phyllocarids and some branchiopod crustaceans (Fig. 6). These animals were large and probably swam slowly in and out of the BBL as morphologically similar crustaceans do today (e.g. Manton 1977). Again, by comparison with extant Crustacea, their foraging strategy was inefficient, a fortiori, when the abundance of suspended, metabolically inert particles (i.e. turbidity) increased (Conover 1968, Poulet 1974, McCabe \& O'Brien 1983). Only food size and coarse-grained features of food distributions (cf. Levins 1968) have been demonstrated as bases for. trophic specializations among these taxa (Wilson 1973, Boyd 1976). Therefore, taxonomic diversity in these groups was low throughout the Phanerozoic.

\section{Crustaceans}

Two adaptive responses to high turbidity, unique to the Crustacea, revolutionized the potential for specialization and evolutionary radiation in aquatic arthropods: high-speed miniaturization and the caridoid facies' (Fig. 7).

High-speed miniaturization occurred independently among the copepods, ostracods and cladoceran branchiopods, and probably among ancestral barnacles (e.g. Fryer 1974, Marcotte 1982, 1983, McKenzie et al. 1983). It is an adaptation which exploits the physics of moving water and permits small animals to selectively feed on a dilute suspension of small food items when foraging amid a dense (relative to the concentration of food) fog of small inert particles (turbidity) in hyperbenthic and pelagic environments (Zaret 1980, see also Ritzrau 1996, Morgan et al 1997). This adaptation seems to have constrained the evolution of larval forms of marine invertebrates (Emlet 1991).

High-speed miniaturization has been most thoroughly studied in modern copepods (e.g. Koehl \& Strickler 1981, Price et al. 1983, Strickler 1984, Tiselius \& Jonsson 1990). When cephalic and thoracic appendages on small aquatic animals are moved at high speeds over short distances, currents or shear fields can be generated that draw suspended particles toward the animals in a non-turbulent, viscosity-dominated, laminar flow (Fig. 7) (e.g. Alcaraz et al. 1980, Koehl \& Strickler 1981, Price et al. 1983). On the benthos, large slow-moving arthropods foraged through a kinematically stable fluid environment (Marcotte 1983). In the plankton, small crustaceans created such an environment. In both cases, non-visual, chemo- and proprioreceptive abilities were used to detect foods by their chemical 'halos' (Strickler \& Bal 1973, Hamner \& Hamner 1977, Poulet \& Marsot 1978, 1980, Friedman 1980). In both environments, feeding was efficient. These taxa are not indiscriminate filterers (cf. Conover 1968, Poulet 1974, McCabe \& O'Brien 1983). Proprioreception in free-living copepods is also important in selecting habitats (e.g. Marcotte 1984) and, for parasitic copepods, in locating hosts (Wong 1996, see also Fields \& Yen 1997).

Sewell (1956) proposed a post-Cretaceous origin for the Copepoda based on biogeographic distributions and patterns of continental movements. Fossils of freeliving copepods are known only from boron-rich lake sediments in the Miocene (Palmer 1960). Fossil parasitic copepods similar to modern taxa have been found

Fig. 6. Representatives of trilobite and crustacean arthropod taxa adapted to benthic habitats and to pelagic and hyperbenthic habitats and their temporal ranges through the Phanerozoic eon. Abbreviations for geologic periods are defined in Fig. 1. Turbidity hypothesis: density of stippling indicates relative levels of turbidity in each period 


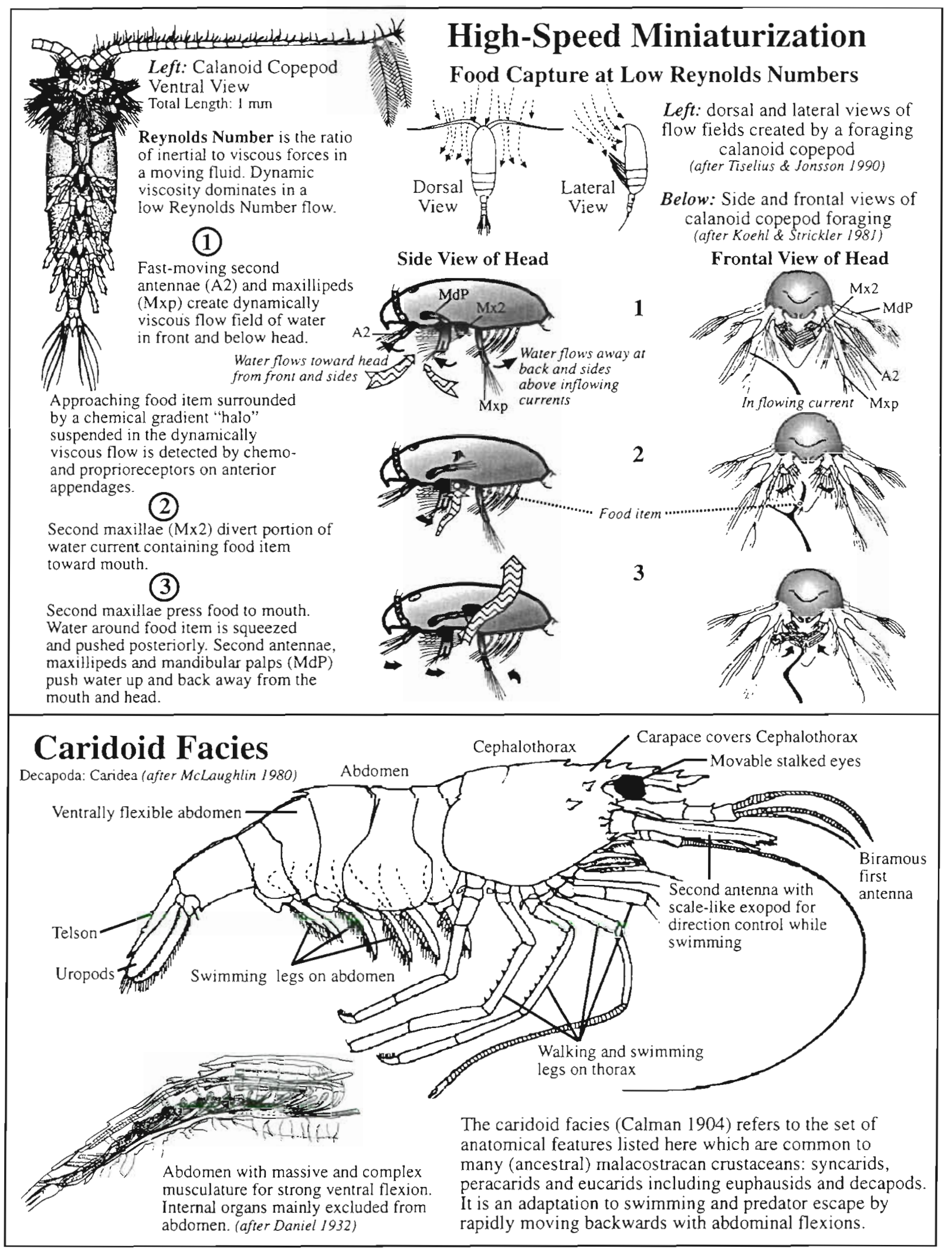

Fig. 7 Anatomical and functional characteristics of the 2 adaptive responses among crustacean taxa to high turbidity: high-speed miniaturization and the caridoid facies 


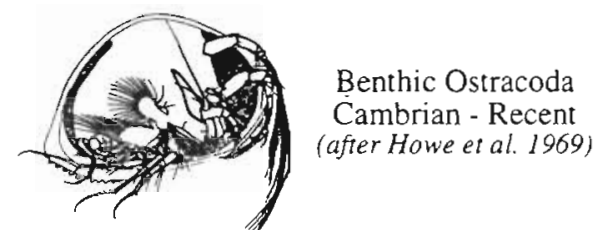

Number of Ostracod Genera

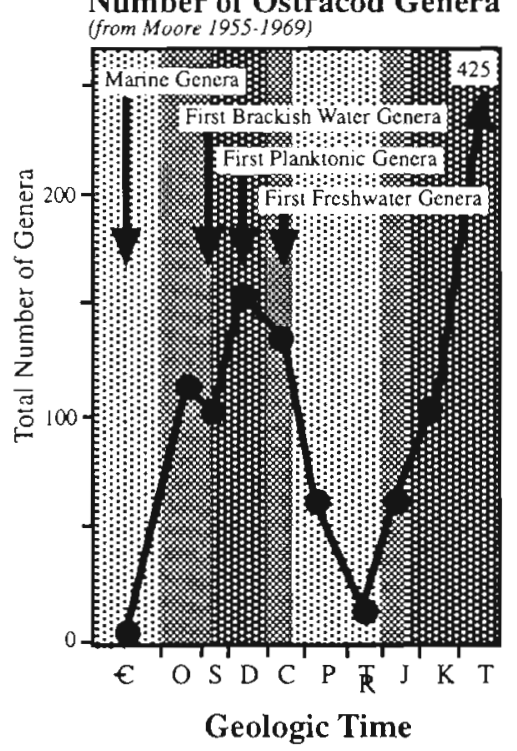

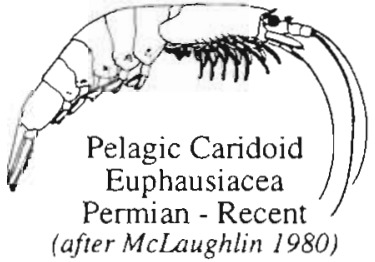

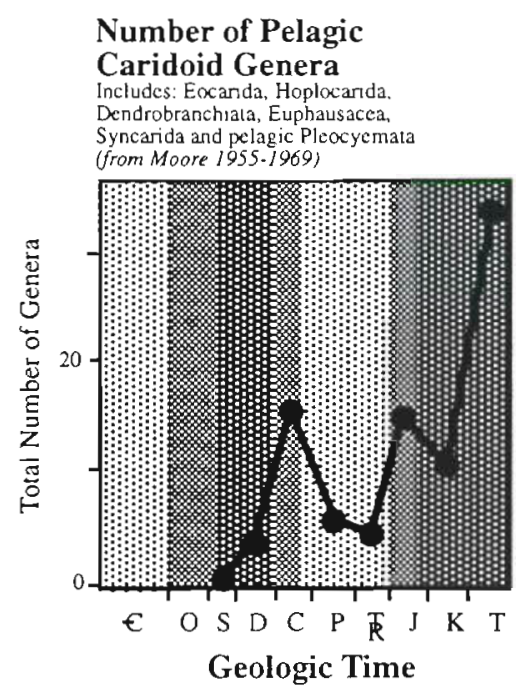

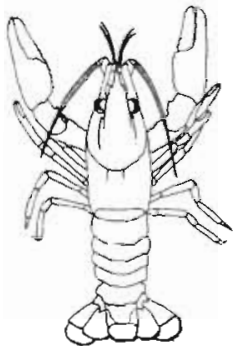

Benthic Caridoid

Decapoda: Lobster Jurassic - Recent (after McLaughlin 1980)

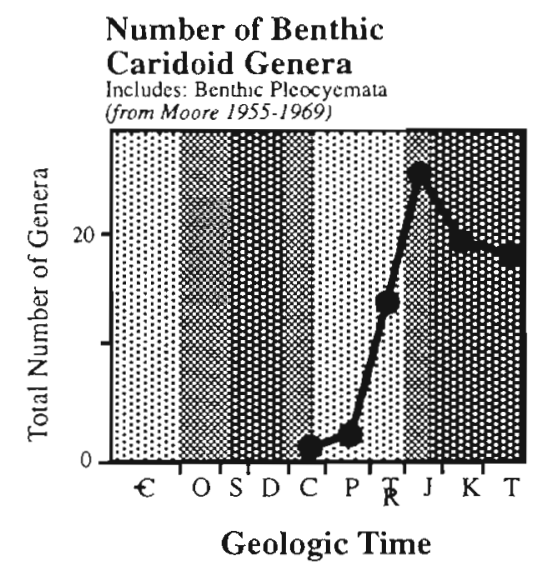

Fig. 8. Generic abundances of ostracod and caridoid crustaceans through geologic time. Variables and axes are designated on each graph. Abbreviations for geologic periods are defined in Fig. 1 Density of stippling indicates relative levels of turbidity in each period. Number of ostracod genera in the Tertiary was off the scale of the graph at 425 genera

on Cretaceous fish (Cressey \& Patterson 1973). If ancestral copepods were free living, the whole taxon may have originated during the first Phanerozoic turbidity maximum; the taxon diversified extensively during and after the second turbidity maximum.

Ostracods radiated into pelagic (as well as nonmarine) habitats during the first Phanerozoic maximum in turbidity (Fig. 8) (Müller 1979, McKenzie et al. 1983). If ancestral barnacles were similar in structure and habit to the cyprid larvae of contemporary cirripeds (Barnard 1892, Newman 1982, 1983), they probably displayed characteristics of high-speed miniaturization. The appendages used to generate foraging currents by ostracods, ancestral barnacles and some cladocerans (the latter known only from the Tertiary onward) were enclosed within a bivalved carapace that altered the hydrodynamics of their foraging strategy (i.e. greater boundary effects, Bernoulli Effect), increasing foraging current speed and apparent viscosity. Unfortunately, little is known of the hydrodynamics within the bivalved carapace of these taxa.

The morphological relationship between the large ancestral crustaceans and their miniaturized descendants has often been explained by invoking the process of neoteny, the retention of formerly juvenile characteristics by adult descendants produced by retardation of somatic development (e.g. Garstang 1922, Dahl 1956,
Schram 1982, Boxshall 1983). Only competition for food size has been proposed as an explanation of what drove this phenomenon (Marcotte 1983). Three more explanations can now be offered based on the observations that neotenous taxa are usually smaller when adult than their ancestors and that small organisms generally have shorter generations and reproduce more frequently than larger taxa (e.g. Fenchel 1974).

(1) The foraging efficiencies of high-speed miniaturization during periods of elevated turbidity, as outlined above, would have strongly selected for neotenous mutations when they occurred.

(2) Neoteny would have facilitated exploitation of small food sources by small herbivores, and these by small carnivores. In this context: small phytoplankton evolved during times of continental fission and high turbidity (e.g. dinoflagellates, see below).

(3) Marine plants and animals whose physiologies and life histories (e.g. life span, reproductive frequency, fecundity) were adapted to the frequency with which resources were provided (e.g. chemical nutrients) or destroyed (e.g. by bottom scour, advection) by ocean turbulence may have become smaller to keep pace with the higher frequencies, shorter durations and smaller areal sizes of turbulent eddies that characterized intercontinental waterways and shallow inland seas during periods of continental fission and high 
turbidity (e.g. Worsley \& Broadhurst 1975, Marcotte 1980, Jablonski \& Flessa 1984). For example, (small) dinoflagellates are adapted to taking up nutrients provided in high frequency fluxes while (large) diatoms are adapted to lower frequency nutrient fluxes (Turpin \& Harrison 1979, Turpin et al. 1981).

Neotenous adaptations to high frequency environmental changes during periods of continental fission may explain the iterative evolution of small entomostracan and ostracod crustaceans during the SilurianDevonian and Jurassic-Present. It also explains the post-Jurassic radiations of neotenous decapod crustaceans (see below and Fig. 8). Conversely, during periods of continental fusion, which were dominated by low frequency environmental changes, large, longer-lived forms evolved, e.g. trilobites in the Cambrian and decapod crustaceans in the Permian-Triassic.

The caridoid facies (Fig. 7), a suite of shrimp-like morphological characters (e.g. Calman 1909, Hessler \& Newman 1975, Hessler 1982, 1983), was the second revolutionary adaptation of crustaceans to high turbidity. The first fossil caridoids - the eocarids and palaeostomatopods (Fig. 6) - appeared during the Devonian turbidity maximum (e.g. Moore 1955-1969, Hessler 1982, 1983, Schram 1982), though their ancestors may have evolved during the Silurian. These taxa possessed stalked compound eyes, presumably of the appositiontype, as do extant decapod larvae and stomatopods (e.g. Land 1981, Di Stefano et al. 1990, Iacino et al. 1990, Cronin et al. 1994). These eyes provided a panoramic view of the environment and, if the eyes of contemporary stomatopods are instructive, were probably adapted to turbid waters in at least 4 ways.

(1) The eyes were large, with wide facet diameters and high values of the 'eye parameter', indicating adaptation to dim light (Horridge 1978).

(2) The eyes were mobile and capable of maintaining a tremor that caused the retinal image to flicker. Visual images must move or flicker on the retina to be perceived (e.g. Cohen 1969, Cronin et al. 1988). Lateral inhibition of ocular elements can be used to physiologically induce flicker, as in the ancestral chelicerate Limulus, that has immovable eyes (Ruck \& Jahn 1954, Ratliff et al. 1967). Light entering the sea flickers more in clear water than in turbid water (McFarland \& Munz 1975, McFarland \& Loew 1983). Physical movement of the eye (tremor) can modulate both external and internal sources of flicker, thus causing edges of objects in the visual field to be accentuated (Horridge \& Sanderman 1964, Horridge 1966) and enabling the perceiver to overcome the inherent luminosity of highly turbid water. Retention of an ancestral, dim-adapted eye in contemporary stomatopods may explain the occurrence of this eye-type in these taxa even though they are often active in bright light (Horridge 1978).
(3) Ommatidia are aligned in a vertical array along the longer axis of the eye and their visual fields overlap. As a result, horizontal motion of vertical edges would be enhanced (Schiff \& Hendrickx 1997).

(4) The eyes contained many types of photopigments; visual information was sampled over a broad spectral range by receptors with narrowly tuned sensitivities (Marshall et al. 1991). This is important because turbidity blocks blue light and transmits yellow-green light (Jerlov 1976, Loew \& McFarland 1990).

These first caridoids swam above the bottom to varying degrees using serially arranged abdominal appendages. They thus avoided the visual limitations of the nepheloid layer and the tactile and chemosensing predators on the bottom (e.g. Marcotte 1983). In pelagic environments, however, they were not free of predation pressures, for ancestral caridoids evolved during the Silurian- 'The Age of Fish' (Romer 1968), To avoid these predators, caridoids possessed a large muscular abdomen with caudal appendages that could be used to propel the animal suddenly backwards away from danger (Fig. 7) (e.g. Calman 1909, Daniel 1932, 1934, Hessler 1983). Caridoids may also have behaviorally avoided visually foraging predators by swimming into more dim, turbid, bottom waters during daylight hours. Diel vertical migrations and crepuscular feeding habits could have originated in this manner. This predatorfree space (sensu Marcotte 1984) near the bottom was exploited at the expense of prolonged foraging in brighter light. To compensate for this compromise, taxa derived from these early caridoids evolved superposition eyes that functioned well in very dim light (e.g. Land 1981, Gaten et al. 1992). Contemporary mysids and euphausids are vestiges of these early derivations and retain both diel migratory behaviors and superposition compound eyes (e.g. Land 1981, Hessler 1982, 1983).

As turbidity decreased in the late-CarboniferousPermian, the benthos re-opened for the adaptive radiation of visual foragers. The caridoids, which had been demersal, now stayed on the bottom; the benthic Peracarida evolved and the decapod crustaceans diversified (Fig. 6) (Fryer 1968, Jansson \& Kallander 1968). Many contemporary peracarids retain their ancestors apposition eyes (Land 1981) although others have secondarily lost their visual capabilities especially with the evolution of cooperative groups (sensu Frank 1995). For example, parental care in amphipods has been described a number of times (e.g. Thiel 1997 and references therein). In the Tanaidacea, benthic tubedwelling, perhaps originally a predator avoidance strategy, evolved into an elaborate mechanism for food cultivation and social care of offspring (Anderson et al. 1978, Johnson \& Attramadal 1982). In these taxa, the image-forming capacity of the eyes was reduced. Pheromones and tactile cues were used to locate 
mates, juveniles and intruders. With the evolution of reflective superposition eyes, which functioned well in dim light (Land 1981), Permian caridoids were able to exploit recently ventilated deep-water habitats (Figs. 4 $\& 8$ ). Interestingly, the pelagic larvae of contemporary benthic decapods recapitulate the apposition eyes of their pelagic caridoid ancestors (Land 1981).

In the Jurassic, when Pangaea II broke apart and turbidity again increased, paguran (hermit) and brachyuran (Cancer-like) crabs evolved (Fig. 6), perhaps through neoteny of a pelagic caridoid ancestor (Gurney 1942). These crabs were the only decapods to retain the ancestral apposition compound eyes (Land 1981) that, in any event, were of little use to them on the turbid benthos. They foraged instead by using their chemosensitive first antennae and were protected from predators by a strong compact exoskeleton and aggressive defense and/or burrowing behaviors (e.g. Gurney 1942, Laverack 1963, Hazlett 1966, Vance 1972).

Chelicerate arthropods, which thrived with the trilobites in early Phanerozoic seas, and uniramian arthropods (e.g. Robison 1990), from which insects evolved, moved into intertidal pools and onto land with the first rise in oceanic turbidity: late-Ordovician-Devonian (e.g. Ratallack \& Feakes 1987, Labandeira et al. 1988, Jeram et al. 1990, Shear et al. 1996). In this way, they escaped the difficulties of perceiving food and predators in a turbid sea and of competing with the new wave' of marine crustaceans. In the clear light of the atmosphere, apposition-type eyes were sufficient and are retained today by Limulus, the sole survivor of marine Paleozoic chelicerate diversity, and by most insects (Ruppert \& Barnes 1994).

\section{Trends among modern Crustacea}

If the volume of preserved sediments is an index of oceanic turbidity, as proposed above, then the Recent ocean has been as turbid as that of the Devonian. It should be noted, however, that the existence of polar ice caps at the present time and the consequent lower eustatic sea level and resultant lack of vast, shallow inland seas substantially limit comparison of contemporary and Devonian oceanic conditions (Clark 1982a,b). The biology of extant crustaceans confirms the similarity between Devonian and Recent (though not present day) oceans. For example, like eurypterid chelicerates during the Silurian-Devonian, some contemporary decapod crabs are evolving terrestrial life styles. They are solving the problem of respiring air with lung-like, internalized chambers (cf. Bliss 1963, Mason 1970, Hanken \& Størmer 1975, Waterston 1975). Their eyes are apposition-type, forming images and detecting polarized light to aid navigation to shoreward burrows after foraging sorties to beaches exposed at low tide (Herrnking 1968, 1972, Young \& Ambrose 1978). The ultimate success of this second invasion of land by aquatic arthropods may depend, in large measure, on the contemporary terrestrial biotic environment, which is filled with potential competitors and predators, unlike that which greeted Devonian eurypterids. Some Tertiary crustaceans, that have remained fully aquatic, have evolved phonoreceptors and sound-producing organs that seem to permit sophisticated, non-visual communication among individuals and perhaps enhance predator detection (e.g. through bow wave detection) and avoidance (e.g. schooling behaviors of euphausiids) in a dim habitat (e.g. Mulligan \& Fischer 1977, Salmon \& Hyatt 1983, Weise 1996). Some crabs have evolved noxious chemical defenses that protect them from predation (Luckenbach \& Orth 1990). Further, the diversification of copepods, cladocerans and ostracods during the Tertiary seems to be yielding a greater diversity of (high-speed) miniaturized forms than ever before.

\section{TESTS OF COROLLARY DEDUCTIONS USING OTHER TAXA}

The hypothesis that oceanic turbidity fluctuated during Phanerozoic time, and that perceptual adaptations, foraging strategies, habitat selection and predator avoidance mechanisms appropriate to these fluctuations have produced alternating patterns of diversifications and extinctions, is a hypothesis which is testable using taxa other than aquatic arthropods. The evolution of plants, mollusks and fish will be considered briefly in this regard.

\section{Plants}

In addition to decreasing the quantity of light that can penetrate water, turbidity changes the depthspecific spectral irradiance (Jerlov 1976, Loew \& McFarland 1990). Blue light is selectively eliminated and yellow-green light is transmitted. In contemporary seas, a soluble yellow pigment ('Gelbstoffe'), probably a complex organic material produced by living aquatic and decaying terrestrial plants, is partially responsible for this color shift (Kalle 1966, Jerlov 1976, Loew \& McFarland 1990). For Phanerozoic marine plants, adaptations for maximizing photosynthetic energy production from a dim light source of changing wavelength became an imperative during the 2 periods of increased turbidity. As a consequence, the diversity of unspecialized green and acritarch algae fell precipitously during the first Phanerozoic period of high turbidity (e.g. Lipps 1970, Leoblich 1974). 
Dinoflagellates, which may have distant ancestors in the Cambrian (Moldowan \& Talyzina 1998), diversified during the Devonian turbidity maximum (e.g. Lipps 1970, Leoblich 1974). Dinoflagellates have auxiliary pigment complexes specialized for absorption of dim light at various wavelengths and are capable of swimming and vertically migrating to stay in brighter surface waters during daylight hours (e.g Tappan 1968, Pitrat 1970, Blasco 1978, Parsons et al. 1984).

Diatoms, which also have accessory pigment systems, originated during the Cretaceous turbidity maximum and depend on frequent episodes of vertical turbulence to remain high in the water column. As outlined above, a correlation of high turbidity and high frequency of vertical turbulence is predicted for periods of continental divergence and shallow inland seas.

During turbidity maxima, selection pressures favoring mutations that helped to support plants on or above the waters' surface (e.g. Macrocystus, Pastalsia), and helped prevent desiccation when plants were exposed to air (e.g. Fucus), may have presaged the movement of plants onto land. The hypothesis that plants moved onto land during the first Phanerozoic rise in turbidity is supported by analysis of spore tetrads (Kenrick \& Crane 1997). Nucleotide sequences in higher plants (Martin et al. 1989) have confirmed a Carboniferous origin. Paleogeochemical data independently support these conclusions, e.g. carbon/sulfur ratios (Fig. 4) (Garrels \& Lerman 1981, Berner \& Raiswell 1983). In context of the environmental change model proposed above, it is interesting to note that in addition to increases in freshwater primary productivity and the ventilation of the deep sea after the Carboniferous, the rise in the carbon/sulfur ratio observed during the Permian-Triassic may have been affected by terrestrial aridity and the dominance of savanna-like biomes in which fires caused an increase in the turnover rate of carbon relative to sulfur and thus increased disproportionately its deposition rate. Continental aridity at this time may have also contributed to a decrease in primary production, recorded in the fossil record as a decrease in the ${ }^{13} \mathrm{C} /{ }^{12} \mathrm{C}$ ratio (Thackerary et al. 1990).

Once land plants had become established, they affected their aquatic ancestors in at least 2 ways. They absorbed nutrients that had previously been washed into the sea (Tappan 1968, 1970) and, through decay of land plants and the resulting production of soluble organic compounds, they amplified and/or modified color shifts in light transmitted through coastal waters (Kalle 1966, Jerlov 1976, Loew \& McFarland 1990). These effects contributed to the rapid decline in marine primary production that seems to have occurred during the Devonian-Permian and from which the oceans may have never fully recovered (Tappan $1968,1970)$.

\section{Suspension feeders: mollusks, brachiopods, bryozoans and crinoids}

Turbidity adversely affects benthic suspension-feeding invertebrates and positively affects benthic deposit feeders (e.g Rhoads 1974). The hypothesis presented here would predict a decline in suspension-feeding diversity during the Devonian, i.e. 150 Myr before the 'mass extinction' of aquatic invertebrates at the PermoTriassic boundary. This prediction is confirmed by the middle-Paleozoic decrease in the contribution of bryozoans, brachiopods and pelmatozoan crinoids to carbonate sediments (Blatt et al. 1972). Although total mollusc diversity followed the general pattern of Phanerozoic changes, that of turbidity-sensitive mollusks did not. The majority of suspension-feeding bivalves, including rock-dwelling forms, became extinct during middle-Paleozoic and post-Triassic turbidity increases (e.g. Fig. 2), while deposit-feeding and swimming taxa diversified (Larson \& Rhoads 1983, Thayer 1983, Valentine 1986, Jablonski \& Raup 1995).

\section{Other mollusks}

Nautiloid cephalopods, which lived in Paleozoic seas, foraged visually and probably had little or no chemoreceptive abilities (Morton 1968, Kohn 1983). As turbidity rose during the Paleozoic, nautiloid diversity fell and pelagic life styles evolved (e.g. Wiedmann 1973, Ward 1984, Kohn 1983, Ward et al. 1984). During the clear water periods of the Mesozoic, ammonoid cephalopods, also visual foragers, originated and quickly diversified (e.g. Moore 1955-1969, Wiedmann 1973). Ammonoid diversity fell precipitously in the turbid waters of the Cretaceous (Marshall \& Ward 1996) and, before their extinction at the Cretaceous-Tertiary boundary, survivors were predominately pelagic like their nautiloid ancestors. In this ocean realm, ammonoids may have been out-competed by fish which possessed a host of non-visual sensory modalities (see below). The one group of pelagic cephalopods to survive the Paleozoic and late-Mesozoic extinctions were nautiloids, such as Nautilus, which had well-developed chemoreceptors in the mantle cavity (osphradia) that, interestingly, may also be mechanoreceptors capable of detecting the abundance of particles suspended in water, i.e. turbidity (Hulbert \& Yonge 1937). Modern squids have an analogue of the lateral line system in fish (Budelmann \& Bleckmen 1988) that permits them to perceive key elements of their environment (see also Aronson 1991).

For paleozoic gastropods, morphological separations between sister-species were 5 times greater in the clear waters of the Cambrian than in the rising turbid- 
ity of the late-Ordovician (Wagner 1995). Turbidity may have been the source of this morphological constraint

\section{Cnidaria: Anthozoa}

Although total anthozoan cnidarian diversity followed the pattern of 'mass extinctions' in the Mesozoic, within-taxon patterns did not. Paleozoic reefs were formed of mostly solitary rugose corals; colonial tabulate corals played only a minor part (Coates \& Oliver 1973). Contemporary reef-building corals are very sensitive to turbidity (e.g. Tomascik \& Sander 1985). Most of the Paleozoic reef corals went extinct in the first turbidity maximum during the Silurian-Devonian (Fig. 2) (Coates \& Oliver 1973). The colonial anthozoans diversified again during the clearing waters of the lateCarboniferous-Permian despite decreases in the areal extent and provinciality of the shallow tropical habitats in which they lived. Hermatypic corals, which require the energetic benefits of primary-producing symbiotic zooxanthellae for growth and form coral reefs in contemporary seas, diversified in the rising turbidity of the Jurassic (e.g. Rosen 1977). Zooxanthellae evolved from several classes of single-cell plant, especially dinoflagellates with their turbidity-adapted pigments (see 'Plants' above). The energetic benefits of symbiotic zooxanthellae notwithstanding, colonial anthozoans again declined in diversity during the second turbidity maximum (Jurassic-Tertiary) (Coates \& Oliver 1973). Turbidity was an overriding selective force for the evolution of reef-building anthozoans and their animalplant associations (e.g. Jablonski \& Flessa 1984, Young \& Scrutton 1991). Thus, the turbidity hypothesis can explain both the long-term evolutionary trends among taxa as well as particular exceptions within these taxa.

\section{Fish}

Fish have a long Paleozoic history. Those that today inhabit turbid environments are predominately nonvisual foragers; those in clear water use vision to forage and locate predators (e.g. Dusenbery 1992, Bond 1996). Accordingly, like crustaceans, fish should show alternations in the distribution of visual and non-visual sensory modalities throughout their evolution. Here the data are less complete but are still in tentative agreement. The length of latero-sensory lines in placoderm fish increased during the Paleozoic turbidity rise (Graham-Smith 1978a,b). Contemporary examples of ancestral fish taxa, e.g. the Salmonidae, which probably originated during the early-mid Mesozoic, are visual foragers (Lauder \& Liem 1983, Marcotte \& Brow- man 1986). Most contemporary fish, which probably originated during the late-Mesozoic-Cenozoic, possess well-developed non-visual sensory modalities, including olfaction, accoustica-lateralis system, ampullae of Lorenzini and possibly magnetic organs, which they use to explore dim turbid and even light-free environments (e.g. Dusenbery 1992, Bond 1996)

\section{CONCLUSION}

The hypothesis of marine Phanerozoic diversity developed here synthesizes the work of geologists, paleoclimatologists and paleontologists with studies of sensory anatomy and behavior of aquatic organisms and allows predictions in such diverse fields as phytoplankton ecology, invertebrate and vertebrate systematics and the evolution of sensory modalities and ethology. This hypothesis emerged from a solipsistic paradigm of evolution which is inclusively uniformitarian, gradualistic and largely qualitative.

Uniformitarianism is the ultimate null hypothesis of historical geology and posits that geological processes have always been (and still are) due to causes or forces operating continuously and with uniformity (e.g. Hull 1973; for important caveats, see for example Norris 1991, Shear 1991, Erwin 1993). Its opposite, Catastrophism-the theory that certain geological and biological phenomena were caused by catastrophes rather than by continuous and uniform processes - is here understood as included in Uniformitarianism; apparent differences are a matter of scale in space and time. Low frequency events such as the continental rifting and movement and relatively high frequency events such as earth-asteroid impacts (e.g Alvarez et al. 1984) or periods of volcanic hyperactivity (e.g. Renne et al. 1995) both affect evolution, but at different scales. High frequency events reinforce the effects of low frequency changes when both frequencies are at their peaks. For example, the number of asteroid collisions with the earth was high during the Devonian (e.g Grieve \& Robertson 1979. Playford et al. 1984, Claeys et al, 1992, McGhee 1996) and at least 1 large asteroid collided with the earth at the end of the Cretaceous (e.g. Alvarez et al. 1984). Air-borne dust and soot produced by these high frequency celestial events may have reinforced the cyclic dimming of marine environments produced by low frequency continental rifting.

Inclusive Uniformitarianism emphasizes that environmental processes act at different scales and frequencies in space and time and are not uniformly appreciated by evolving marine taxa. Quantitative indices of taxonomic change in the fossil record alone cannot capture the proximate causes of evolution amid the sample bias and alias which confounds the record. 
The hypothesis of Phanerozoic diversity outlined here rests on an examination of qualitative features of taxa in the fossil record, especially perceptual modalities, foraging strategies, predator avoidance mechanisms, habitat specializations and the behavioral ecology these adaptations imply. This hypothesis generated a number of predictions which, when tested, confirmed the particulars of the model.

Gradualism is closely associated with Uniformitarianism and emphasizes that the earth changes constantly but gradually (e.g. Desmond \& Moore 1991). The hypothesis presented here and the paradigm from which it was developed do not require (but do not exclude) episodes of rapid evolutionary change, such as those which would be associated with punctuated equilibria (e.g. Eldredge \& Gould 1972). Rather, they provide a context within which to understand them if and when they do occur. As with Uniformitarianism, Gradualism is a matter of scale-the scale of the organism experiencing change. Marine taxa appreciate different rates of environmental change; what is gradual to a whale may be abrupt to a barnacle. Qualitative features of adaptation, such as mobility, body size and reproductive rates, are important in assessing what rates of environmental change are experienced by a particular organism.

Finally, this paradigm is solipsistic: environmental variables must be understood as the study organism appreciates them and at that organism's scale in space and time. This paradigm strikes at the heart of the vestigial Newtonian 'Objective Observer', which remains in the calculus of evolution theory (e.g. Marcotte 1983). When environmental variables are understood as an organism appreciates them, conceptual dichotomies such as Uniformitarianism versus Catastrophism and Gradualism versus abrupt instantaneous change become less antagonistic and more heuristic. This paradigm accepts that taxa evolve uniquely, adaptations have multiple causes and consequences, and divorcing an adaptation from the organism that gave rise to it gives the adaptation an abstract reality it does not deserve. This paradigm also explicitly emphasizes the importance of perception in assessing adaptive strategies. Perception connects an organism to a stimulus through representations (cf. 'search images' in models of foraging behavior); representations make distinctions and have attributes unique to the organism producing them (e.g. Fodor 1980, Pylyshyn 1980). It is the representation and not the stimulus that should be taken as the act of perception, as it is the representation to which the organism responds and ultimately adapts; stimulus is not experience just as physics is not the science of meter reading (e.g. Marcotte 1983). Though perception is on the cutting edge of selection pressure, evolutionary perceptual and cognitive ecolo- gies are still nascent sciences (cf. Marcotte 1983, Dusenbery 1992, Dukas 1998 and references cited therein). They contribute not only new characteristics for phylogenetic analyses but a new paradigm from which integrated multidisciplinary hypotheses can spring.

Acknowledgements. I thank Dr H. I. Browman for his many helpful comments and textual revisions and the librarians at Brown University for their patient assistance.

\section{LITERATURE CITED}

Aksnes DL, Utne ACW (1997) A revised model of visual range in fish. Sarsia 82:137-1.47

Alcaraz M, Paffenhöer GA, Strickler JR (1980) Catching the algae: a first account of visual observations on filter-feeding calanoids. In: Kerfoot WC (ed) Evolution and ecology of zooplankton communities. University Press of New England, Manchester, p 241-248

Alvarez W, Kauffman EG, Surlyk F, Alvarez LW, Asaro F, Michel HV (1984) Impact theory of mass extinctions and the invertebrate fossil record. Science 223:1135-1141

Anderson A, Hallberg E, Johnson SB (1978) The fine structure of the compound eye of Tanais cavolinii Milne-Edwards (Crustacea: Tanaidacea). Acta Zool 59:49-55

Aronson RB (1991) Ecology paleobiology and evolutionary constraints in the octopus. Bull Mar Sci 49:245-255

Balsam WL, Deaton BC (1991) Sediment dispersal in the Atlantic Ocean: evaluation of visible light spectra. Rev Aquat Sci 4:411-447

Barnard HM (1892) The Apodidae: a morphological study. MacMillan, London

Benton MJ (1995) Diversification and extinction in the history of life. Science 268:52-58

Bergström J (1969) Remarks on the appendages of trilobites. Lithaia 2:395-414

Bergström J (1973) Organization, life and systematics of trilobites. Fossils Strata 2:1-69

Berner RA (1976) The benthic boundary layer from the viewpoint of a geochemist. In: McCave $\mathrm{N}$ (ed) The benthic boundary layer. Plenum Press, New York, p 33-45

Berner RA (1990) Atmospheric carbon dioxide levels over Phanerozoic time. Science 249:1382-1386

Berner RA, Raiswell R (1983) Burial of organic carbon and pyrite sulfur in sediments over Phanerozoic time: a new theory. Geochem Cosmochim Acta 47:855-862

Berry WB, Wilde $P$ (1978) Progressive ventilation of the oceans - an explanation for the distribution of the lower Paleozoic black shales. Am. J Sci 278:257-275

Blackman RB, Tukey JW (1958) The measurement of power spectra. Dover, New York

Blasco D (1978) Observations on the diel migrations of marine dinoflagellates off the Baja California coast. Mar Biol 46 : $41-52$

Blatt H, Middleton G, Murray R (1972) Origin of sedimentary rocks, Prentice-Hall, Englewood Cliffs

Bliss DE (1963) The pericardial sacs of terrestrial Brachyura. In: Whittington HB, Rolfe WDI (eds) Phylogeny and evolution of Crustacea. Harvard University Press, Cambridge, p $59-78$

Block HD, Nilsson NJ, Duda RO (1964) Determination and direction of features in patterns. In: Tow JT, Wilcox WL (eds) Computer and information sciences. Spartan Books, Washington, p 75-110 
Bond CE (1996) Biology of fishes. Saunders College Publ, New York

Bond GC, Nickeson PA, Kominz MA (1984) Breakup of a supercontinent between $625 \mathrm{Ma}$ and $555 \mathrm{Ma}$ : new evidence and implications for continental histories. Earth Planet Sci Lett 70:325-345

Bowen ZP, Rhoads DC, McAlester AL (1974) Marine benthic communities in the Upper Devonian of New York. Lethaia $7: 93-122$

Boxshall GA (1983) A comparative functional analysis of the major maxillopodan groups. Iñ: Schram FR (ed) Crustacean phylogeny. Balkema, Rotterdam, p 121-143

Boyd CM (1976) Selection of particle sizes by filter-feeding copepods: a plea for reason. Limnol Oceanogr 21:175-180

Briggs DEG (1977) Bivalved arthropods from the Cambrian Burgess Shale of British Columbia. Palaeontology 20 : 595-621

Briggs DEG (1978) The morphology mode of life and affinities of Canadaspis perfecta Middle Cambrian Burgess Shale British Columbia. Phil Trans R Soc Lond B281:439-487

Broadhurst FM, Loring DH (1970) Rates of sedimentation in the Upper Carboniferous of Britain. Lethaia 3:1-9

Broecker WS, Denton GH (1989) The role of ocean-atmosphere reorganizations in glacial cycles. Geochim Cosmochim Acta 53:2465-2501

Brooks HK (1969) Palaeostomatopoda. In: Moore RC (ed) Treatise on invertebrate paleontology. University of Kansas Press, Lawrence, p R5.33-R535

Bruton DL (1981) The arthropod Sidneyia inexpectans middle Cambrian Burgess Shale British Columbia. Phil Trans R Soc Lond B295:619-653

Budelmann BU, Bleckmen H (1988) A lateral line analogue in cephalopods: water waves generate microphonic potentials in the epidermal head lines of Sepia and Lolliguncula. J Comp Physiol A Sens Neural Behav Physiol 164:1-6

Calman WT (1904) On the classification of the Crustacea Malacostraca. Ann Mag Nat Hist 13(7th Ser):144-158

Calman WI (1909) Crustacea. In: Lankester R (ed) A treatise on zoology, Vol VII. Adam and Black, London, p 1-346

Campbell KSW (1975) The functional morphology of Cryptolithus. Fossils Strata 4:65-86

Cannon HG (1933) On the feeding mechanism of the Branchiopoda. Phil Trans R Soc Lond B222:267-352

Chlupac I (1975) The distribution of phacopid trilobites in space and time. Fossils Strata 4:399-408

Cisne JL (1975) Anatomy of Triarthrus and the relationships of the Trilobita. Fossils Strata 4:45-64

Claeys P, Casier JG, Margolis SV (1992) Microtektites and mass extinctions: evidence for a Late Devonian asteroid impact. Science 257:1102-1104

Clark DL (1982a) Origin nature and world climate effect of Arctic Ocean ice cover. Nature 300:321-325

Clark DL (1982b) The Arctic Ocean and post Jurassic paleoclimatology. In: Berger WH, Crowell JC (eds) Climate in earth history. Academic Press, Washington, p 133-138

Clarke JM (1889) The structure and development of the visual area in the trilobite Phacops rana Green (Sic). J Morph 2: $253-270$

Clarkson ENK (1967) Environmental significance of eye reduction in trilobites and recent arthropods. Mar Geol 5: $367-375$

Clarkson ENK (1975) The crolution of the eye in trilobites. Fossils Strata 4:7-32

Clarkson ENK (1986) Invertebrate palaeontology and evolu. tion. Allen and Unwin, London

Clarkson ENK, Levi-Setti R (1975) Trilobite eyes and the optics of Des Cartes and Huygons. Nature 254:663-667
Coates $\mathrm{AG}_{i}$ Oliver WA (1973) Coloniality in zoantharian corals. In: Boardman RS, Cheetham AH, Oliver WA (eds) Animal colonies: development and function through time. Dowcten Hutchinson \& Ross, Philadelphia, p 3-27

Cohen J (1969) Sensation and perception. I. Vision. Rand McNally \& Co, Chicago

Conover RJ (1968) Zooplankton - life in a nutritionally dilute environment. Am Zool 8:107-118

Cowen R, Kelley JS (1976) Stereoscopic vision within the schizochroal eve of trilobites. Nature 261:130-131

Cressey R, Patterson C (1973) Fossil parasitic copepods from a Lower Cretaceous fish. Science 180:1283-1285

Cronin TM, Raymo ME (1997) Orbital forcing of deep-sea benthic species diversity. Nature 385;624-626

Croniri TW, Nair JN, Doyle RD, Caldwell RL (1988) Ocular tracking of rapidly moving visual targets by stomatopod crustaceans. J Exp Biol 138:155-179

Cronin TW, Marshall NJ, Land MF (1994) The unique visual system of the mantis shrimp. Am Sci 82:356-365

Dahl E (1956) Some crustacean relationships. In: Wingstrand KG (ed) Bertil Hanstrom: zoological papers in honour of his sixty-fifth birthday November 20th 1956. Zoological Institute, Lund, p 1.38-147

Daniel RJ (1932) Comparative study of the abdominal musculature in Malacostraca. Part III, the abdominal muscular systems of Lophogaster typicus, M. Sars, and Gnathophausia zoëa, Suhm, and their relationships with the musculatures of other malacostraca. Proc Trans Liverpool Biol Soc 47:71-133

Daniel RJ (1934) The abdominal muscular systems of Paranaspides lacustris (Smith). Lancashire Sea-Fish Lab Rep 1933:26-44

Davies TA, Hay WW, Southam JR, Worsley TR (1977) Estimates of Cenozoic ocean sedimentation rates. Science $197.53-55$

Desmond A, Moore J (1991) Darwin: the life of a tormented evolutionist. Warner Books, New York

Di Stefano G, lacino L, Schiff $H$ (1990) What the mantis shrimp's eve (possibly) tells its raptorial appendages. Biol Cybern 63:393-401

Dryer K (1976) Gradients of velocity and physical biological and chemical properties. In: McCave $\mathrm{N}$ (ed) The benthic boundary layer. Plenum Press, New York, p 211-229

Dukas R (1998) Cognitive ecology. University of Chicago Press, Chicago

Duntley SQ (1962) Underwater visibility. In: Hill MN (ed) The sea, Vol 1. Interscience, New York, p 452-45s

Dusenbery DB (1992) Sensory ecology. WH Freenan \& Co, New York

Eiane K, Aksnes DL, Giske J (1997) The significance of optical properties in competition among visual and tactile plantivores: a theoretical study. Ecol Model 98:123-136

Eldredge $N$ (1971) Patterns of cephalic musculature in the Phacopina (Trilobita) and their phylogenetic significance. J Paleontol 45:52-67

Eldredge N (1972) Systematics and evolution of Phacops rana (Green 1932) and Phacops iowensis Delo 1935 (Trilobita) from the Middle Devonian of North America. Bull Am Mus Nat Hist 147:1-113

Eldredge N, Gould SJ (1972) Punctuated equilibria: an alternative to phyletic gradualism. In: Schopf TJM (ed) Models in paleobiology. Freeman Cooper \& Company, San Francisco, p 82-115

Emlet RB (1991) Functional constraints on the evolution of larval forms of marine invertebrates: experimental and comparative evidence. Am Zool 31:707-725

Erwin DH (1993) The origin of metazoan development: a 
palaeobiological perspective. Biol J Linn Soc Lond 50 $255-274$

Feist R (1995) Effect of paedomorphosis in eye reduction patterns of evolution and extinction in trilobites. In: Mc Namara KJ (ed) Evolutionary change and heterochrony John Wiley \& Sons, New York, p 225-244

Fenchel T (1974) Intrinsic rate of natural increase: the relationship with body size. Oecologia 14:317-326

Fields DM, Yen J (1997) The escape behavior of marine copepods in response to a quantifiable fluid mechanical disturbance. J Plankton Res 19:1289-1304

Fischer AG (1988) The two phanerozoic supercycles. In: Berggren WA, Van Couvering JA (eds) Catastrophes and earth history: the new uniformitarianism. Princeton University Press, Princeton, p 129-150

Fodor JA (1980) Methodological solipsism considered as a research strategy in cognitive psychology. Behav Brain Sci 3:63-73

Fortey RA (1974) A new pelagic trilobite from the Ordovician of Spitsbergen, Ireland and Utah. Palacontology 17 $111-1.24$

Fortey RA (1975) Early Ordovician trilobite communities Fossils Strata 4:339-360

Fortey RA (1981) Prospectatrix genatenta (Stubblefield) and the trilobite superfamily Cyclopygacea. Geol Mag 118 603-614

Fortey RA (1985) Pelagic trilobites as an example of deducing the life habits of extinct arthropods. Trans R Soc Edinb 76 $219-230$

Fortey RA (1989) There are extinctions and extinctions: examples from the lower Paleozoic. Phil Trans R Soc Lond B326: $327-355$

Fortey RA, Morris SF (1977) Variation in lens packing of Phacops (Trilobita). Geol Mag 1.14:25-32

Frakes LA (1979) Climates throughout geologic time. Elsevier, Amsterdam

Francois R, Bacon MP (1991) Variations in terrigenous input into the deep equatorial Atlantic during the past 24,000 years. Science 251:1473-1476

Frank SA (1995) Mutual policing and repression of competition in the evolution of cooperative groups. Nature 377. $520-522$

Friedman MM (1980) Comparative morphology and functional significance of copepod receptors and oral structures. In: Kerfoot WC (ed) Ecology and evolution of zooplankton communities. University Press of New England New York, p 185-197

Fryer G (1968) Evolution and adaptive radiation in the Chydoridae (Crustacea: Cladocera): a study in comparative functional morphology and ecology. Phil Trans R Soc Lond B254:221-385

Fryer G (1974) Evolution and adaptive radiation in the Macrothricidae (Crustacea: Cladocera): a study in comparative functional morphology and ecology. Phil Trans R Soc Lond B269:137-272

Garrels RM, Lerman A (1981) Phanerozoic-cycles of sedimentary carbon and sulfur. Proc Natl Acad Sci USA 78 $4652-4656$

Garrels RM, Mackenzie FT (1971) Evolution of sedimentary rocks. Norton, New York

Garstang W (1922) The theory of recapitulation: a critical restatement of the biogenic law. Zool J Linn Soc Lond 35 81-101

Gaten E, Sheldon PMJ, Herring PJ (1992) Regional morphological variations in the compound eyes of certain mesopelagic shrimps in relation to their habifat. J Mar Biol Assoc UK 72:61-.75
Graf. G, Rosenberg R (1997) Bioresuspension and bıodeposition: a review. J Mar Syst 11:269-278

Graham-Smith W (1978a) On some variations in the laterosensory lines in the placoderm fish Bothnolepis. Phil Trans R Soc Lond B282:1-39

Graham-Smith W (1978b) On the lateral lines and dermal bones in the parietal region of some crossopterygian and dipnoan fishes. Phil Trans R Soc Lond B282.41-105

Gregor ( $B$ (1968) The rate of denudation in post-Algonkian time. K Ned Akad Wet Proc 71:22-32

Grieve RAF, Robertson PB (1979) The terrestrial cratering record. I. Current status of observations. Icarus 38:212-229

Gurney R (1942) Larvae of decapod crustacea. Ray Society, London

Hamner P, Hamner WM (1977) Chemosensory tracking of scent trails by the planktonic shrimp Acetes sibogae australis. Science 195:886-888

Hanken NM, Stormer L (1975) The trail of a large Silurian eurypterid. Fossils Strata 4:255-270

Hansen JE, Lacis AA (1990) Sun and dust versus greenhouse gases: an assessment of their relative roles in global climate change. Nature 346:713-719

Hansen JE, Lacis AA, Ruedy R (1990) Comparison of solar and other influences on long-term climate. In: Schatten $\mathrm{KH}$, Arking A (eds) Climate impact of solar variability, NASA Conference Publication 3086. NASA, Greenbelt, p 135-145

Harrington HJ (1959) General description of Trilobita. In: Moore RC (ed) Treatise on invertebrate paleontology. University of Kansas Press, Lawrence, p O38-O117

Harrington HJ, Henningsmoen $G$, Howell BF, Jaanusson V, Lochman-Balk C, Moore RC, Poulsen C, Rasetti F, Richter E, Richter R, Schmidt H, Sdzuy K, Struve W, Tripp R, Weller JM, Whittington HB (1959) Systematic descriptions. In: Moore RC (ed) Treatise on invertebrate paleontology. University of Kansas Press, Lawrence, p 0170-O540

Hatfield CB, Camp MJ (1970) Mass extinctions correlated with periodic galactic events. Bull Geol Soc Am 81. 911-919

Hazlett BA (1966) Factors affecting the aggressive behaviour of the hermit crab Calcinus tibicen. Z Tierpsychol 6:655-671.

Hermking WF (1968) Adaptive visually oriented behaviour. Am Zool 8:585-598

Herrnking WF (1972) Orientation in shore-limited arthropods especially the sand fiddler crab. In: Winn HE, Olla BL (eds) Behaviour of marine animal invertebrates, Vol 2. Plenum Press, New York, p 1-59

Hessler RR (1969) Peracarida. In: Moore RC (ed) Treatıse on invertebrate paleontology. University of Kansas Press, Lawrence, p R360-R393

Hessler RR (1982) Evolution within the Crustacea. Part 1: Remipedia, Branchiopoda and Malacostraca In: Abele LG (ed) Biology of crustacea, Vol 1. Academic Press, New York, p 149-185

Hessler RR (1983) A defense of the caridoid facies: wherein the early evolution of the Eumalacostraca is discussed. In: Schram FR (ed) Crustacean phylogeny. Balkema, Rotterdam, p $145-164$

Hessler RR, Newman WA (1975) A trilobitomorph origin for the Crustacea. Fossils Strata 4:437-459

Hinze JO (1959) Turbulence: an introduction to its mechanism and theory McGraw-Hill, New York

Hoffman PF (1991) Did the breakout of Laurentia turn Gondwarlaland inside out? Science 252:1409-1412

Horridge GA (1966) Perception of edges versus areas by the crab Carcinus. J Exp Biol 44:247-254

Horridge GA (1978) The separation of visual axes in apposition compound eyes. Phil Trans R Soc Lond 285:1-59 
Horridge GA, Sanderman DC (1964) Nervous control of the optokinetic responses of the crab Carcinus. Proc $\mathrm{R}$ Soc Lond B161:216-246

Howe HV, Kesling RV, Scott HW (1969) Morphology of living Ostracoda. In: Moore RC (ed) Treatise on invertebrate paleontology. University of Kansas Press, Lawrence, p Q3-Q17

Hulbert GCEB, Yonge CM (1937) A possible function of the osphradium in the Gastropoda. Nature 139:840-841

Hull D (1973) Darwin and his critics. Harvard University Press, Cambridge

Hupé P (1953) Trilobites. In: Piveteau J (ed) Traité de paléontologie. Masson et Cie., Paris, p 44-246

lacino L, Di Stefano G, Schiff H (1990) A neural model for localizing targets in space accomplished by the eye of the mantis shrimp. Biol Cybern 63:383-391

Isozaki Y (1997) Permo-Triassic boundary superanoxia and stratified superocean: records from lost deep sea. Science $276: 235-238$

Jablonski D. Flessa KW (1984) The taxonomic structure of shallow-water marine faunas: implications for Phanerozoic extinctions. Am Malacol Bull 2:79-80

Jablonski D, Raup DM (1995) Selectivity of end-Cretaceous marine bivalve extinctions. Science 268:389-391

Jablonski D, Sepkoski JJ, Bottjer DJ, Sheehan PM (1983) Onshore-offshore patterns in the evolution of Phanerozoic shelf communities. Science 222:1123-1125

Jansson BO, Kallander $C$ (1968) On the diurnal activity of some littoral peracarid crustaceans in the Baltic Sea. J Exp Mar Biol Ecol 2:24-36

Jeram AJ, Selden PA, Edwards D (1990) Land animals in the Silurian: arachnids and myriapods from Shropshire England. Science 250:658-661.

Jerlov NG (1976) Marine optics. Elsevier, Amsterdam

Johnson SB, Attramadal YG (1982) Reproductive behaviour and larval development of Tanais cavolinii (Crustacea: Tanaidacea). Mar Biol 71:11-16

Kalle K (1966) The problem of the Gelbstoff in the sea Oceanogr Mar Biol Annu Rev 4:91-104

Kenrick P, Crane PR (1997) The origin and early evolution of plants on land. Nature 389:33-39

Kerr RA (1991) The stately cycles of ancient climate. Science 252:1254-1255

Kerr RA (1999) Early life thrived despite earthly travails. Science 284:2111-2113

Kiørboe T (1997) Small-scale turbulence marine snow formation and planktivorous feeding. Sci Mar 61:141-158

Koehl MAR, Strickler JR (1981) Copepod feeding cur̃eñts food capture at low Reynolds number. Limnol Oceanogr 26:1062-1073

Kohn AJ (1983) Feeding biology of Gastropods. In: Saleuddia ASM, Wilber KM (eds) The mollusca, Vol 5. Academic Press, New York, p 1-63

Labandeira CC, Beall BS, Hueber FM (1988) Early insect diversification: evidence from a Lower Devonian bristletail from Québec. Science 242:913-916

Land MF (1981) Optical mechanisms in the higher Crustacea with a comment on their evolutionary origins. In: Laverack MS, Cosens DJ (ed) Sense organs. Blackie, Glasgow, p $31-48$

Larson DW, Rhoads DC (1983) The evolution of infaunal communities and sedimentary fabrics. In: Trevesz MJS, McCall PC (eds) Biotic interactions in recent and fossiI benthic communities. Plenum Press, New York, p 627-649

Lauder GV, Liem KF (1983) Patterns of diversity and evolution in ray-finned fishes. In: Northcutt RG, Davis RE (eds) Fish. neurobiology, Vol 1. Brain stem and sense organs. University of Michigan Press, Ann Aībor, p 2-24
Laverack MS (1963) Aspects of chemoreception in Crustacea Comp Biochem Physiol 8:141-151

Leg 138 Shipboard Scientific Party (1991) Ancient oceanclimate links. Nature 353:304-305

Leoblich AR (1974) Protistan phylogeny as indicated by the fossil record. Taxon 23:277-290

Levins R (1968) Evolution in changing environments. Princeton University Press, Princeton

Lipps JH (1970) Plankton evolution. Evolution 24:1-22

Lisitzin AP (1972) Sedimentation in the world ocean. Soc Econ Paleontol Mineral Spec Publ 17

Liu HS (1992) Frequency variations of the earth's obliquity and the 100-kyr ice-age cycles. Nature 358:397-399

Loew ER, McFarland WN (1990) The underwater visual environment. In: Douglas R, Djamgoz MBA (eds) The visual system of fish. Chapman \& Hall, London, p 1-27

Luckenbach MW, Orth RJ (1990) A chemical defense in Crustacea. J Exp Mar Biol Ecol 137:79-87

Lythgoe JN (1979) The ecology of vision. Clarendon Press, Oxford

Maiorana VC (1981) Prey selection by sight: random or economical. Am Nat 118:450-451

Manabe S, Bruccoli AJ (1990) Mountains and arid climates of middle latitudes. Science 247:192-195

Manton SM (1977) The arthropoda: habits functional morphology and evolution. Clarendon Press, Oxford

Marcotte BM (1980) The meiobenthos of fjords: a review and prospectus. In: Freeland HJ, Farmer DM, Levings CD (eds) Fjord oceanography. Plenum Press, New York, p 557-568

Marcotte BN (1982) Copepoda. In: Abele LG (ed) Biology of crustacea. Vol 1. Academic Press, New York, p 185-197

Marcotte BM (1983) The imperatives of copepod diversity: perception, cognition, competition and predation. In: Schram FR (ed) Crustacean phylogeny. Balkema, Rotterdam, p $47-72$

Marcotte EM (1984) Behaviourally defined ecological resources and speciation in Tisbe (Copepoda: Harpacticoida). J Crustac Biol 4:404-416

Marcotte BM, Browman HI (1986) Foraging behaviour in fish: perspectives on variance. Environ Biol Fish 16:25-33

Marshall CR, Ward PD (1996) Sudden and gradual molluscan extinctions in the latest Cretaceous of western european Tethys. Science 274:1360-1363

Marshall NJ, Land MF, King CA, Cronin TW (1991) The compound eyes of mantis shrimps (Crustacea Hoplocarida Stomatopoda) II. Colour pigments in the eyes of stomatopod crustaceans: polychromatic vision by serial and lateral filtering. Phil Trans R Soc Lond B334:57-84

Martin W, Gierl A, Saedler H (1989) Molecular evidence for pre-Cretaceous angiosperm origins. Nature 339:46-48

Mason CA (1970) Function of the pericardial sacs during the molt cycle in the land crab Gecarcinus lateralis. J Exp Zool $174: 381-390$

McCabe GD, O'Brien WJ (1983) The effects of suspended silt on feeding and reproduction of Daphnia pulex. Am Midl Nat 110:324-337

McFarland WN, Loew ER (1983) Wave produced changes in underwater light and their relation to vision. Environ Biol Fish 8:173-184

McFarland WN, Munz FW (1975) The evolution of photic visual pigments in fish. Vis Res 15:1071-1080

McGhee GR (1996) The Late Devonian mass extinction: the Frasnian/Famennian crisis. Columbia University Press, New York

McGhee GR, Sutton RG (1981) Late Devonian marine ecology and zoogeography of the central Appalachians and New York, Lethaia 14:27-43 
McKenzie KG, Müller KJ, Gramm MN (1983) Phylogeny of Ostracoda. In: Schram FR (ed) Crustacean phylogeny Balkema. Rotterdam, p 29-46

McKunney ML (1997) Extinction vulnerability and selectivity combining ecological and paleontological views. Annu Rev Ecol Syst 28:495-516

Mclaughlin PA (1980) Comparative morphology of recent Crustacea. WH Freeman and Co, San Francisco

McNamara KJ (1980) Evolutionary trends and their functional significance in chasmopine trilobites. Lethaia 13:61-78

Mikulic DG (1981) Trilobites in Paleozoic carbonate buildups. Lethaig 14:45-56

Miller J (1974/75) The sensory fields and life modes of Phacops rana (Green 1832) (Trilobita). Trans $R$ Soc Edinb 69 $337-367$

Miller J (1975) Structure and function of trilobite terrace lines Fossils Strata 4:155-178

Milliman JD, Meade RH (1983) World-wide delivery of river sediment to the oceans. J Geol 91:1-21

Moldowan JM, Talyzina NM (1998) Blogeochemical evidence for dinoflagellate ancestors in the early Cambrian. Science 281:1168-1:170

Moore RC (1955-1969) Treatise of invertebrate paleontology University of Kansas Printing Service, Lawrence

Morgan CA, Cordell JR, Simenstad CA (1997) Sink or swim? Copepod population maintenance in the Columbia River estuarine turbidity-maxima region. Mar Biol 129:309-317 ton JE (1968) Molluscs. Hutchinson. University Press, London

Müller KJ (1979) Phosphatocopine ostracodes with preserved appendages from the Upper Cambrian of Sweden. Lethaia 12:1-27

Müller KJ, Walossek D (1985) Skaracarida, a new order of Crustacea from the Upper Cambrian of Västergötland Sweden. Fossils Strata 17:1-65

Müller KJ, Walossek D (1987) Morphology, ontogeny and life habits of Agnostus pisiformis from the Upper Cambrian of Sweden. Fossils Strata 19:1-124

Mulligan BE, Fischer R (1977) Sounds and behavior of the spiny lobster Panulirus argus (Latreille 1804) (Decapoda: Palinuridae). Crustaceana 32:185-199

Nance RD, Worsley TR, Moody JB (1986) Post-Archean biogeochemical cycles and long-term episodicity in tectonic processes. Geology 14:514-518

Nance RD, Worsley TR, Moody JB (1988) The supercontinent cycle. Sci Am 259(1):72-79

Neuman G, Pierson WJ (1966) Principles of physical oceanography. Prentice-Hall, Englewood Cliffs

Newman WA (1982) Cirripedia. In: Abele LG (ed) Biology of crustacea, Vol 1. Academic Press, New York p 197-220

Newman WA (1983) Origin of the Maxillopoda; Urmalacostracan ontogeny and progenesis. In: Schram FR (ed) Crustacean phylogeny. Balkema, Rotterdam, p 105-119

Norris RD (1991) Biased extinction and evolutivatry trends. Paleobiology 17:388-399

Palmer AR (1960) Miocene copepods from the Mojave Desert California. J Paleontol 34:447-452

Parsons TR, Takahashi M. Hargrave B (1984) Biological oceanographic processes, 3rd edn. Pergamon Press, Oxford

Piper JDA (1982) The Precambrian paleomagnetic record: the case for the Proterozoic Supercontinent. Earth Planet Sci Lett 59:61-89

Piper JDA. (1987) Palaeomagnetism and the continental crust. Open University Press, Milton Keynes

Pitrat CW (1970) Phytoplankton and the late Paleozoic wave of extinction. Palaeogeogr Palaeoclimatol Palaeoecol 8 : $49-55$
Playford PE, McLaren DJ, Orth CJ, Gilmore JS, Goodfellow WD (1984) Iridium anomaly in the Upper Devonian of the Canning Basin western Australia. Science 226:437-439

Poulet SA (1974) Seasonal grazing of Pseudocalanus minutus on particles. Mar Biol 25:109-123

Poulet SA, Marsot P (1978) Chemosensory grazing by marine calanoid copepods (Arthropoda: Crustacea). Science 200: $1403-1405$

Poulet SA, Marsot P (1980) Chemosensory feeding and foodgathering by omnivorous marine copepods. In: Kerfoot WC (ed) Ecology and evolution of zooplankton communities. University Press of New Encland, New York, p 198-218

Powell CM, Li ZX, McElhinny MW, Meert JG, Park JK (1993) Paleomagnetic constraints on timing of the Neoproterozoic breakup of Rodinia and the Cambrian formation of Gondwana. Geology 21:889-892

Price HJ, Paffenhöfer GA, Strickler JR (1983) Modes of cell capture in calanoid copepods. Limnol Oceanogr 28: $116-123$

Purcell EM (1977) Life at low Reynolds number. Am J Phys $45: 3-11$

Pylyshyn ZW (1980) Computation and cognition: issues in the foundation of cognitive science. Behav Jirain Sci 3: $111-169$

Rampino MR, Strothers RB (1984) Terrestrial mass extinctions cometary impacts and the sun's motion perpendicular to the galactic plane. Nature 308:709

Ratallack GJ, Feakes CR (1987) Trace fossil evidence for Late Ordovician animals on land. Science 235:61-63

Ratliff F, Knight BW, Toyoda JI, Hartline HK (1967) Enhancement of flicker by lateral inhibition. Science 158:392-393

Raup DM (1972) Taxonomic diversity during the Phanerozoic. Science 1.77:1065-1071

Raup DM (1993) Ten years in the library: new data confirm. paleontological patterns. Paleobiology 19:43-51

Raup DM, Sepkoski JJ [1984) Periodicities of extinctions in the geologic past. Proc Natl Acad Sci USA 81:801-805

Raup DM. Sepkoski JJ (1988) Testing for periodicity of extinction. Science 241:94-96

Renne PR, Zichao Z, Richards MA, Black MT, Basu AR (1995) Synchrony and causal relations between Permian-Triassic boundary crises and Siberian flood volcanism. Science 269:1413-1416

Rhoads DC (1974) Organism-sediment relations on the muddy sea floor. Oceanogr Mar Biol Annu Rev 12:263-300

Ritzrau W (1996) Microbial activity in the benthic boundary layer small-scale distribution and its relationship to the hydrodynamic regime. J Sea Res 36:171-180

Robinson PL (1973) Palaeoclimatology and continental drift. In: Tarling DH, Runcorn SK (eds) Implications of continental drift to the earth sciences, Vol 1. Academic press London, p 451-476

Robinson RA (1972) Hypostome of agnostid trilobites. Lethaid $5: 239-248$

Robinson RA (1975) Species diversity among agnostid trilo bites. Fossils Strata 4:219-226

Robison RA (1990) Earliest-known uniramous arthropod Nature 334:163-164

Romer AS (1968) The vertebrate body. WB Saunders Company, Philadelphia

Ronov AB (1959) On the post Cambrian geochemical history of the atmosphere and hydrosphere. Geochemistry 5 493-506

Rosen BR (1.977) The distribution of Recent hermatypic corals and its palaeontological significance. Mem Bur Rech Géo. Minièr 89:507-517

Rosenblatt F (1962) Principles of neurodynamics: perceptrons 
and the theory of brain mechanisms. Spartan Press, Washington

Ruck P, Jahn TL (1954) Electrical studies on the compound eye of Ligia occidentalis Dana (Crustacea: Isopoda). J Gen Physiol 37:825-849

Ruppert EE, Barnes RD (1994) Invertebrate zoology. Saunders College Publ, New York

Salmon M, Hyatt GW (1983) Communication. In: Vernberg FJ, Vernberg WB (eds) The biology of Crustacea, Vol 7. Behavior and ecology. Academic Press, New York, p 1-40

Salop LJ (1977) Relationship of glaciations and rapid changes in organic life to events in outer space. Int Geol Rev 19: $1271-1291$

Schiff H, Hendrickx ME (1997) An introductory survey of ecological and sensory receptors of tropical eastern Pacific crustaceans. Ital J Zool 64:13-30

Schlanger SO, Jenkyns HC (1976) Cretaceous oceanic anoxic events: causes and consequences. Geologie Mijnbouw 55: $179-184$

Schmalfus H (1981) Structure patterns and function of cuticular terraces in trilobites. Lethaia 14:331-341

Schoener TW (1979) Generality of the size-distance relation in models of optimal feeding. Am Nat 114:902-914

Schram FR (1982) The fossil record and evolution of Crustacea. In: Abele LG (ed) Biology of Crustacea, Vol 1. Academic Press, New York, p 93-147

Scotese CR, McKerrow WS (1990) Revised world maps and introduction. In: McKerrow WS, Scotese CR (eds) Palaeozoic palaeogeography and biogeography. Memoir 12 . Geological Society, London, p 1-21

Sepkoski JJ (1991) A model of onshore-offshore change in faunal diversity. Paleobiology 17:58-77

Sepkoski JJ, Bambach RK, Raup DM, Valentine JW (1983) Phanerozoic marine diversity and the fossil record. Nature 293:435- 437

Sewell RBS (1956) The continental drift theory and the distribution of the Copepoda. Proc Linn Soc Lond 166:149-177

Shanmugam G, Moiola RJ (1982) Eustatic control of turbidites and winnowed turbidites. Geology 10:231-235

Shear WA (1991) The early development of terrestrial ecosystems. Nature 351:283-289

Shear WA, Gensel PG, Jeram AJ (1996) Fossils of large terrestrial arthropods from the Lower Devonian of Canada. Nature 384:555-557

Signor PW (1982) Species richness in the Phanerozoic: compensating for sampling bias. Geology 10:625-628

Strickler JR (1975a) Swimming in planktonic Cyclops species (copepods: crustacea): pattern movements and their control. In: Wu TYT, Brokaw CJ, Brennan C (eds) Swimming and flying in nature. Plenum Press, New York, p 559-613

Strickler JR (1975b) Intra- and interspecific information flow among planktonic copepods: receptors. Int Ver Theor Angew Limnol Verh 19:2951-2958

Strickler JR (1984) Sticky water: a selective force in copepod evolution In: Meyers DG, Strickler JR (eds) Trophic interactions within aquatic ecosystems. Westview Press, Boulder, p 2-44

Strickler JR, Bal A.K (1973) Setae of the first antenna of the copepod Cyclops scutifer (Sars): their structure and importance. Proc Natl Acad Sci USA 70:2656-2659

Størmer L (1949) Classe Trilobita. In: Grasse PP (ed) Traité de zoologie. Masson et Cie., Paris, p 159-197

Størmer L (1959) Trilobitoidea. In: Moore RC (ed) Treatise on invertebrate paleontology. University of Kansas Press, Lawrence, $\mathrm{p}$ O23-O37

Stubblefield CJ (1959) Evolution in trilobites. Q J Geol Soc Lond 115:145-162
Tappan H (1968) Primary production, isotopes, extinctions and the atmosphere. Palaeogeogr Palaeoclimatol Palaeoecol 4:187-210

Tappan H (1970) Phytoplankton abundance and late Paleozoic extinctions: a reply. Palaeogeogr Palaeoclimatol Palaeoecol $8: 56-66$

Thackerary JF, van der Merwe NJ, Lee-Thorp JA, Sillen A Lanham JL, Smith R, Keyser A, Monteiro PMS (1990) Changes in carbon isotope ratios in the late Permian recorded in therapsid tooth apatite. Nature 347:751-753

Thayer CW (1983) Sediment-mediated biological disturbance and the evolution of marine benthos. In: Trevesz MJS McCall PL (eds) Biotic interactions in recent and fossil benthic communities. Plenum Press, New York, p 479-625

Thiel M (1997) Another caprellid amphipod with extended parental care: Aeginina longicornis. J Crustac Biol 17: $275-278$

Tipper JC (1975) Lower Silurian animal communities-three case histories. Lethaia 8:287-299

Tiselius P, Jonsson PR (1990) Foraging behaviour of six calanoid copepods: observations and hydrodynamic analysis Mar Ecol Prog Ser 66:23-33

Tomascik T, Sander F (1985) Effects of eutrophication on reef building corals. Part 1: growth rates of a reef building coral Monastrea annularis Ellis and Solander. Mar Biol 87: $143-155$

Towe KM (1973) Trilobite eyes: calcified lenses in vivo. Science 179:1007-1009

Turpin DH, Harrison PJ (1979) Limiting nutrient patchiness and its role in phytoplankton ecology. J Exp Mar Biol Ecol 39:151-162

Turpin DH, Parslow JS, Harrison PJ (1981) On limiting nutrient patchiness and phytoplankton growth: a conceptual approach. J Plankton Res 3:421-432

Ullmann JR (1973) Pattern recognition techniques. Crane Russak \& Co, New York

Valentine JW (1973) Phanerozoic taxonomic diversity: a test of alternate models. Science 180:1078-1079

Valentine JW (1986) The Permian-Triassic extinction event and invertebrate developmental modes. Bull Mar Sci 39 $607-615$

Valentine JW, Moores EM (1970) Plate-tectonic regulation of faunal diversity and sea level: a model. Nature 228; $657-659$

Valentine JW, Moores EM (1972) Global tectonics and the fossil record. J Geol 80:167-184

Vance RR (1972) The role of shell adequacy in behavioral interactions involving hermit crabs. Ecology 53: 1075-1083

Wagner PJ (1995) Testing evolutionary constraint hypotheses with early Paleozoic gastropods. Paleobiology 21 : $248-272$

Waples DW (1983) Reappraisal of anoxia and organic richness with emphasis on Cretaceous of North America. Am Assoc Petrol Geol Bull 67:693-978

Ward P (1984) On the cretaceous extinction of the ammonite cephalopods. Am Malacol Bull 2:79

Ward P, Carlson B, Weekly M, Brumbaugh B (1984) Remote telemetry of daily vertical and horizontal movement of Nautilus in Palau. Nature 309:248-250

Waterston CD (1975) Gill structures in the lower Devonian eurypterid Tarsopterella scotica. Fossils Strata 4:241-254

Weil AB, Van der Voo R, Niocaill CM, Meert JG (1998) The Proterozoic supercontinent Rodinia: paleomagnetically derived reconstructions for 1100 to $800 \mathrm{Ma}$. Earth Planet Sci Lett 154:13-24

Weise K (1996) Sensory capacities of euphausiids in the context of schooling. Mar Fresh Behav Physiol 28:183-194 
Whitman JM, Davies TA (1979) Cenozoic oceanic sedimentation rates: how good are the data? Mar Geol 30:269-284

Whittington HB (1975) Trilobites with appendages from the Middle-Cambrian Burgess Shale British Columbia. Fossils Strata 4:97-136

Whittington HB (1977) The Middle Cambrian trilobite Naraoia Burgess Shale British Columbia. Phil Trans R Soc Lond B974:409-443

Whittington $\mathrm{HB}$ (1981) Rare arthropods from the Burgess Shale Middle Cambrian British Columbia. Phil Trans R Soc Lond B292:329-357

Wiedmann J (1973) Evolution or revolution of ammonoids at Mesozoic system boundaries. Biol Rev 48:159-194

Wilcle P, Berry WBN (1984) Destabilization of the oceanic density structure and its significance to marine 'extinction' events. Palaeogeogr Paleoclimatol Palaeoecol 48:143-162

Wilson DS (1973) Food size selection among copepods. Ecology 54:909-914

Wimbush M (1976) The physics of the benthic boundary layer. In: McCave $\mathrm{N}$ (ed) The benthic boundary layer. Plenum Press, New York, p 3-10

Wong CK (1996) Response of copepods to hydromechanical stimuli. Crustaceana 69:853-859

Editorial responsibility: Howard Browman (Contributing Editor), Storebo, Norway
Worsley D, Broadhurst FM (1975) An environmental study of Silurian atrypid communities from southern Norway. Lethaia 8:271-286

Worsley TR, Nance D, Moody JB (1984) Global tectonics and eustasy for the past 2 billion years. Mar Geol 58:373-400

Worsley TR, Nance D, Moody JB (1986) Tectonic cycles and the history of the earth's biogeochemical and paleoceanographic record. Paleoceanography 1:233-263

Young DY, Ambrose HW (1978) Underwater orientation in the sand fiddler crab Uca pugilator. Biol Bull 155:248-288

Young GA, Scrutton CT (1991) Growth form in Silurian heliolitid corals: the influence of genetics and environment. Paleobiology 17:369-387

Young GM (1995) Are Neoproterozoic glacial deposits preserved on the margins of Laurentia related to the fragmentation of two supercontinents? Geology 23:153-156

Zaret RE (1980) The animal and its viscous environment. In: Kerfoot WC (ed) Ecology and evolution of zooplankton communities. University Press of New England, New York, p 3-9

Ziegler AM, Scotese CR, McKerrow WS, Johnson ME, Bambach RK (1979) Paleozoic paleogeography. Ann Rev Earth Planet Sci 7:473-502

Submitted: April 29, 1998; Accepted: August 19, 1999 Proofs received from author(s): December 22, 1999 